\title{
Volcano Hazards Assessment for Medicine Lake Volcano, Northern California
}

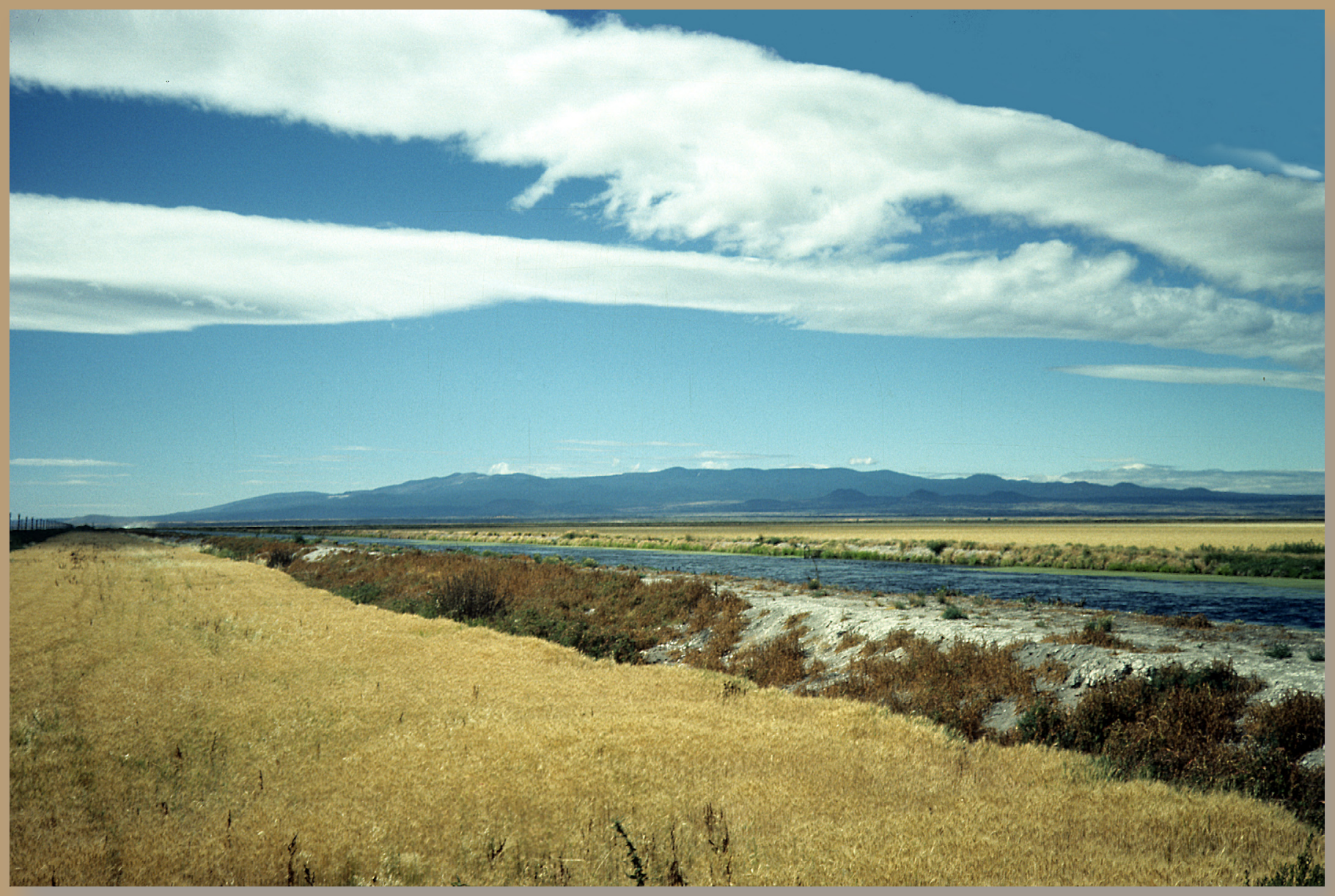

Scientific Investigations Report 2007-5174-A

U.S. Department of the Interior U.S. Geological Survey 


\section{Volcano Hazards Assessment for Medicine Lake Volcano, Northern California}

By Julie M. Donnelly-Nolan, Manuel Nathenson, Duane E. Champion, David W. Ramsey, Jacob B. Lowenstern, and John W. Ewert

Scientific Investigations Report 2007-5174-A 


\section{U.S. Department of the Interior DIRK KEMPTHORNE, Secretary}

\section{U.S. Geological Survey Mark D. Myers, Director}

\section{U.S. Geological Survey, Reston, Virginia: 2007}

This report and any updates to it are available online at:

http://pubs.usgs.gov/sir/2007/5174/a/

For product and ordering information:

World Wide Web: http//www.usgs.gov/pubprod

Telephone: 1-888-ASK-USGS (1-888-275-8747)

For more information on the USGS - the Federal source for science about the Earth, its natural and living resources, natural hazards, and the environment:

World Wide Web: http://www.usgs.gov

Telephone: 1-888-ASK-USGS (1-888-275-8747)

Any use of trade, product, or firm names in this publication is for descriptive purposes only and does not imply endorsement of the U.S. Government.

Although this report is in the public domain, permission must be secured from the individual copyright owners to reproduce any copyrighted materials contained within this report.

Suggested citation:

Donnelly-Nolan, J.M., Nathenson, Manuel, Champion, D.E., Ramsey, D.W., Lowenstern. J. B., and Ewert. J.W., 2007, Volcano hazards assessment for Medicine Lake volcano, northern Californa: U.S. Geological Survey Scientific Investigations Report 2007-5174-A, 26 p., 1 plate.

Cataloging-in-publication data are on file with the Library of Congress (http://www.loc.gov/).

Produced in the Western Region, Menlo Park, California

Manuscript approved for publication, August 20, 2007

Text edited by Peter Stauffer

Layout and design by Judy Weathers

FRONT COVER

View of Medicine Lake volcano from the northeast. Numerous cinder cones can be seen scattered across its surface. Lava Beds National Monument is located on the lower northern flank of the volcano. 


\section{Contents}

Abstract

About Medicine Lake volcano ..............................................................................................

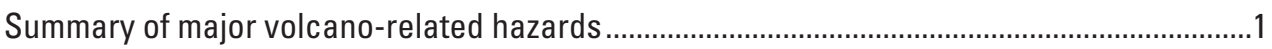

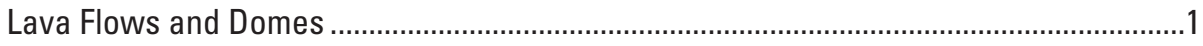

Caldera-Related Hazards ...............................................................................................

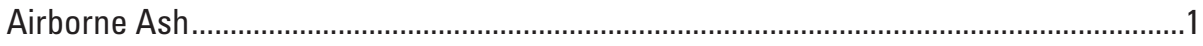

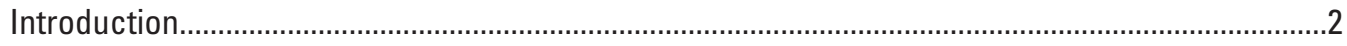

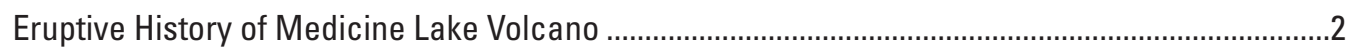

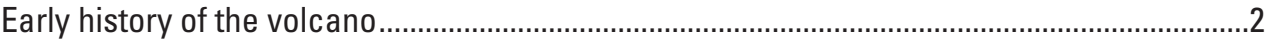

Eruptive activity from 100,000 years until 13,000 years ago .......................................................

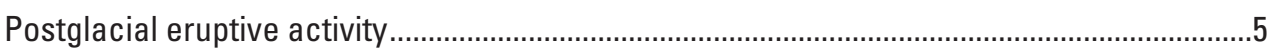

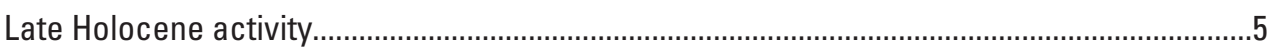

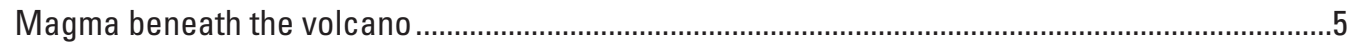

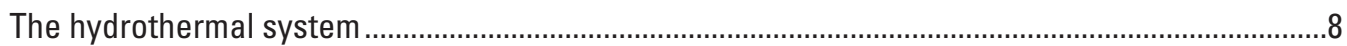

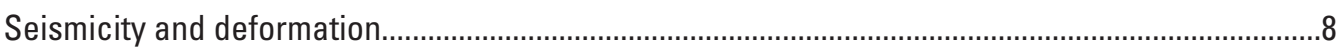

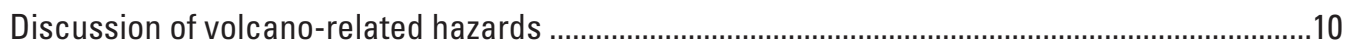

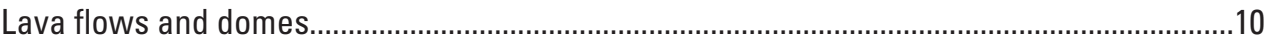

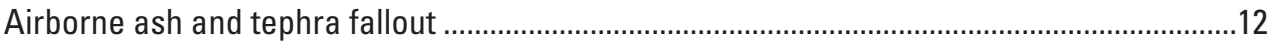

Medicine Lake caldera and associated hazards .................................................................12

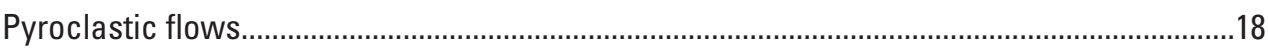

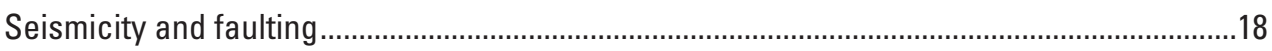

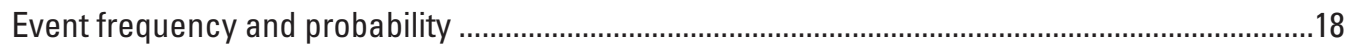

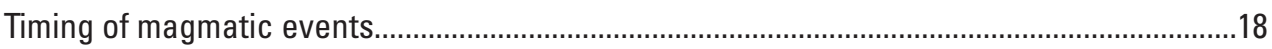

Probability of occurrence and likely volumes of future eruptions ...........................................19

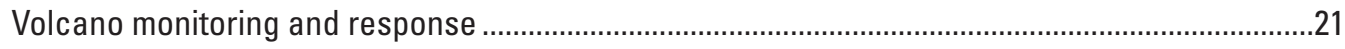

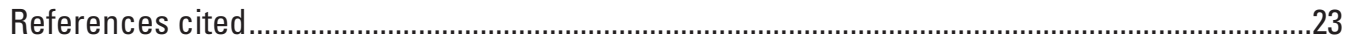

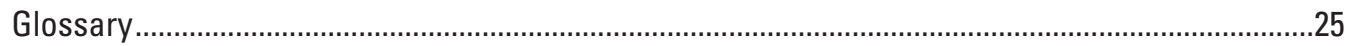

\section{Plate}

[in pocket]

1. Volcano hazards assessment for Medicine Lake volcano, northern California

\section{Figures}

1. Map showing Medicine Lake volcano and vicinity ……..........................................................

2. Map showing selected Medicine Lake volcano lava flows .........................................................

3. Map showing postglacial lava flows at Medicine Lake volcano .............................................

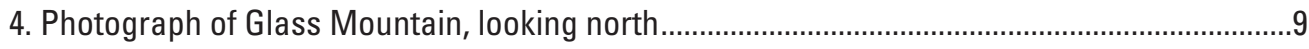

5. Photograph of High Hole Crater cinder cone and Burnt Lava Flow .......................................

6. Photograph of the Mayfield Fault showing offset on fault .....................................................10 
7. Photograph of ground cracks formed during eruption of rhyolite of Little Glass Mountain about 1,000 years ago ................................................................................11

8. Hazard zonation map of Medicine Lake volcano ...................................................................13

9. Map showing isopachs of known late Holocene tephra deposits at

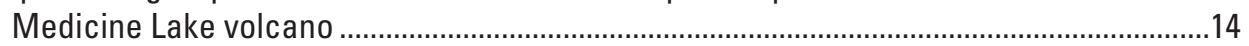

10. Wind rose and histogram showing wind directions in vicinity of Medicine Lake volcano ....15

11. Map showing annual probability of tephra accumulation .......................................................16

12. Aerial view looking west across Medicine Lake caldera toward Mount Shasta ....................16

13. Map showing caldera features and caldera-related hazards...............................................17

14. Photograph of dead cedar tree in edge of Glass Mountain flow...........................................18

15. Diagram showing timing of postglacial eruptions, inferred intrusions, and events in world history …………………………..............................................19

16. Graph of conditional probability that an eruption will occur at Medicine Lake volcano in the next year, given a time since the last eruption...........................................20

17. Graph of probability that an eruption will have a volume or area greater than a given volume or area .............................................................................................20

18. Photograph showing seismometer installation on upper west side of Medicine Lake volcano .............................................................................................................21

\section{Tables}

1. Chronology, area, and volume of postglacial eruptions at Medicine Lake volcano......................8

2. The USGS alert-notification system for volcanic activity .......................................................22 


\section{Conversion factors and datum information}

\begin{tabular}{|c|c|c|}
\hline Multiply & By & To obtain \\
\hline \multicolumn{3}{|c|}{ Length } \\
\hline centimeter $(\mathrm{cm})$ & 0.3937 & inch (in.) \\
\hline millimeter (mm) & 0.03937 & inch (in.) \\
\hline meter $(\mathrm{m})$ & 3.281 & foot $(\mathrm{ft})$ \\
\hline kilometer (km) & 0.6214 & mile (mi) \\
\hline meter $(\mathrm{m})$ & 1.094 & yard (yd) \\
\hline \multicolumn{3}{|c|}{ Area } \\
\hline square meter $\left(\mathrm{m}^{2}\right)$ & 0.0002471 & acre \\
\hline square kilometer $\left(\mathrm{km}^{2}\right)$ & 0.3861 & square mile $\left(\mathrm{mi}^{2}\right)$ \\
\hline \multicolumn{3}{|c|}{ Volume } \\
\hline cubic kilometer $\left(\mathrm{km}^{3}\right)$ & 0.2399 & cubic mile $\left(\mathrm{mi}^{3}\right)$ \\
\hline
\end{tabular}

Temperature in degrees Celsius $\left({ }^{\circ} \mathrm{C}\right)$ may be converted to degrees Fahrenheit $\left({ }^{\circ} \mathrm{F}\right)$ as follows:

$$
{ }^{\circ} \mathrm{F}=\left(1.8 \mathrm{x}^{\circ} \mathrm{C}\right)+32
$$

Temperature in degrees Fahrenheit $\left({ }^{\circ} \mathrm{F}\right)$ may be converted to degrees Celsius $\left({ }^{\circ} \mathrm{C}\right)$ as follows:

$$
{ }^{\circ} \mathrm{C}=\left({ }^{\circ} \mathrm{F}-32\right) / 1.8
$$

Vertical coordinate information is referenced to the "North Geodetic Vertical Datum of 1929

(NGVD 29)"

Horizontal coordinate information is referenced to the "North American Datum of 1927 (NAD 27)"

Altitude, as used in this report, refers to distance above the vertical datum. 


\title{
Volcano Hazards Assessment for Medicine Lake Volcano, Northern California
}

\author{
By Julie M. Donnelly-Nolan, Manuel Nathenson, Duane E. Champion, David W. Ramsey, Jacob B. Lowenstern, \\ and John W. Ewert
}

\section{Abstract}

\section{About Medicine Lake Volcano}

Medicine Lake volcano (MLV) is a very large shieldshaped volcano located in northern California where it forms part of the southern Cascade Range of volcanoes. It has erupted hundreds of times during its half-million-year history, including nine times during the past 5,200 years, most recently 950 years ago. This record represents one of the highest eruptive frequencies among Cascade volcanoes and includes a wide variety of different types of lava flows and at least two explosive eruptions that produced widespread fallout. Compared to those of a typical Cascade stratovolcano, eruptive vents at MLV are widely distributed, extending $55 \mathrm{~km}$ northsouth and $40 \mathrm{~km}$ east-west. The total area covered by MLV lavas is $>2,000 \mathrm{~km}^{2}$, about 10 times the area of Mount St. Helens, Washington. Judging from its long eruptive history and its frequent eruptions in recent geologic time, MLV will erupt again. Although the probability of an eruption is very small in the next year (one chance in 3,600 ), the consequences of some types of possible eruptions could be severe. Furthermore, the documented episodic behavior of the volcano indicates that once it becomes active, the volcano could continue to erupt for decades, or even erupt intermittently for centuries, and very likely from multiple vents scattered across the edifice.

Owing to its frequent eruptions, explosive nature, and proximity to regional infrastructure, MLV has been designated a "high threat volcano" by the U.S. Geological Survey (USGS) National Volcano Early Warning System assessment. Volcanic eruptions are typically preceded by seismic activity, but with only two seismometers located high on the volcano and no other USGS monitoring equipment in place, MLV is at present among the most poorly monitored Cascade volcanoes.

\section{Summary of Major Volcano-Related Hazards}

\section{Lava Flows and Domes}

The most likely future eruption at MLV would be a small basaltic lava flow a few kilometers in length on the flank of the volcano, accompanied by local near-vent explosive activity that would build a cinder cone or spatter cone. Hazards would include violent ejection of hot blocks of lava on ballistic trajectories near the vent, as well as intermittent explosive pyroclastic eruptions that could send ash clouds several kilometers into the air and deposit local accumulations of ash. Also possible, but much less likely, would be eruption of fluid basalt flows that extend tens of kilometers from the vent area, cover as much as a few hundred square kilometers, and could continue for decades. Eruption of silicic lavas, including rhyolite and dacite, would likely be confined to the upper parts of the volcano. Such events probably would begin with explosive eruptions sending tephra many kilometers into the atmosphere, as well as generating local pyroclastic flows and surges. Growing lava domes could collapse to form local avalanches of hot rock, although silicic domes and lava flows themselves are not likely to extend more than a few kilometers from their vents.

\section{Caldera-Related Hazards}

Five of the nine eruptions of MLV in the past 5,200 years have taken place in or at the margin of the summit caldera. Located at the center of the volcano, the $7 \times 12-\mathrm{km}$ caldera contains the namesake Medicine Lake, a 1x2-km body of water bordered by campgrounds and private cabins. In the unlikely event of an eruption through the lake, the mixing of water and magma could produce phreatomagmatic explosions. The immediate area of the lake, including the campgrounds and cabins, would be blanketed by muddy, possibly hot tephra. Eruptions of lava flows or domes in or near the caldera would probably be preceded by explosive eruptions that could deposit many meters of pumice near the vents. Any such flows would advance slowly, but if they reached the lake, local explosive activity might occur. Small pyroclastic flows could be generated by the collapse of steep silicic flow fronts. Before and during magmatic intrusions and eruptions, gases, including carbon dioxide, sulfur dioxide, and hydrogen sulfide, can be transported to the surface. The closed topography formed by the caldera rim around Medicine Lake could allow toxic gases to pond during periods of extended calm wind conditions, potentially resulting in asphyxiation.

\section{Airborne Ash}

Although only a few tephra layers are recorded among the documented products of MLV eruptions, two late Holo- 
cene rhyolite eruptions that took place about 1,000 years ago generated significant tephras that extend tens of kilometers from the vents and likely rose high into the atmosphere to levels that today could affect air travel. A similar eruption in the future could potentially affect the largest nearby city, Klamath Falls, Oregon, if winds were from the south. Smaller ash eruptions accompanying the construction of cinder cones would affect much smaller near-vent areas, but these also could interfere with low-flying aircraft. Volcanic ash and coarser debris also can induce respiratory problems, cause hazardous driving conditions, interfere with communications, short out power lines, contaminate feed for livestock, and damage any electronic or motorized equipment. Once dry, volcanic ash deposits can be remobilized by wind and remain troublesome long after an eruption ceases.

See plate 1 for a concise presentation of the material in this report, and see the glossary at the back of the report for explanation of geologic terms.

\section{Introduction}

Medicine Lake volcano (MLV) forms a broad shieldshaped edifice (cover photo) located in the northern California part of the Cascade Range. The volcano began erupting half a million years ago and has erupted at least 16 times since the end of the last ice age about 13,000 years ago. Nine eruptions have taken place in the last 5,200 years, most recently about 950 years ago. The volcano (fig. 1; see also plate 1) rises a kilometer above the surrounding terrain, and at its center is the $7 \times 12-\mathrm{km}$ caldera that contains its namesake, Medicine Lake. The total north-south reach of lava flows from MLV is $\sim 80 \mathrm{~km}$ and maximum east-west extent is $\sim 50 \mathrm{~km}$; they thus cover an area about 10 times larger than the area of Mount St. Helens and its surrounding volcanic fan. Mount St. Helens, however, has generated a far greater number of explosive eruptions than MLV.

Two main types of eruptions, corresponding with different chemical compositions of lava dominate the history of the volcano. Rhyolite and dacite, the lavas with the highest silica contents, have erupted mostly on the upper parts of the volcano. Eruptions of these lavas typically begin with an early explosive phase, which may generate significant far-traveled tephra, but their lava flows advance only a few kilometers at most from their vents because they are very viscous. Mafic lava flows of basalt, basaltic andesite, and andesite composition have lower silica contents and are much more fluid. They most commonly erupt on the flanks of the volcano and are dominantly effusive, flowing quietly out of the vent. However, they are typically accompanied by early local pyroclastic activity that builds a cinder cone or spatter cone. Some basalt flows are very large, erupting from multiple vents and covering as much as $300 \mathrm{~km}^{2}$. Overall, vents for MLV eruptions are widely distributed across the edifice, spanning $\sim 55 \mathrm{~km}$ north-south by $\sim 35 \mathrm{~km}$ east-west. A single large pyroclastic eruption about 180,000 years ago contributed to formation of the caldera and produced the volcano's only ash-flow tuff, a widespread pyroclastic deposit that is present in all sectors of the volcano.

The volcano includes portions of Modoc, Klamath, and Shasta-Trinity National Forests (fig. 1), and those areas are managed by the U.S. Forest Service. Few people live on the volcano, although National Park Service (NPS) staff live on the north flank in Lava Beds National Monument (fig. 1). That NPS-administered area covers about 10 percent of the volcano and hosts campgrounds and about 100,000 visitors each year. The caldera encompasses several U.S. Forest Service campgrounds in addition to private cabins adjacent to Medicine Lake. Hundreds of people can be present around the lake on busy summer weekends. During the winter, snow accumulates on the upper part of the volcano and roads are not plowed, so access to higher elevations during the winter months is limited. A major utility corridor (fig. 1), including three power lines and a pair of natural gas pipelines, connects California to the Pacific Northwest and Canada.

A previous hazards assessment of Medicine Lake volcano was published in Miller (1989). Subsequent detailed geologic mapping of the volcano (Donnelly-Nolan, in press) provides the basis for the present hazards assessment, which focuses on eruptive activity since about 100,000 years ago (fig. 2), and especially on postglacial (less than 13,000 years ago) activity, as a guide to the kinds and magnitudes of eruptions to be expected in the future. This report describes the various types of volcano-related hazardous events that might occur at MLV in the future on the basis of new understanding of past behavior at the volcano. It also estimates the probability and types of future eruptions and describes monitoring equipment that could be installed in order to provide advance warning of impending eruptions. In the National Volcano Early Warning System (NVEWS) assessment, MLV is designated a "high threat volcano" (Ewert and others, 2005). Despite this designation, only two seismometers are currently installed at the volcano. Careful leveling surveys have documented nearly $1 \mathrm{~cm}$ per year of current subsidence at the center of the volcano, but no USGS Global Positioning System (GPS)-based network is installed to monitor ground movement on an ongoing basis.

The information in this report is summarized on plate 1. Technical geologic terms are explained in the glossary at the back of the report.

\section{Eruptive History of Medicine Lake Volcano}

\section{Early History of the Volcano}

The oldest known lavas at MLV are about 500,000 years old (Donnelly-Nolan and Lanphere, 2005). Samples collected from exploratory geothermal drill holes indicate that the early history of the volcano was dominated by 


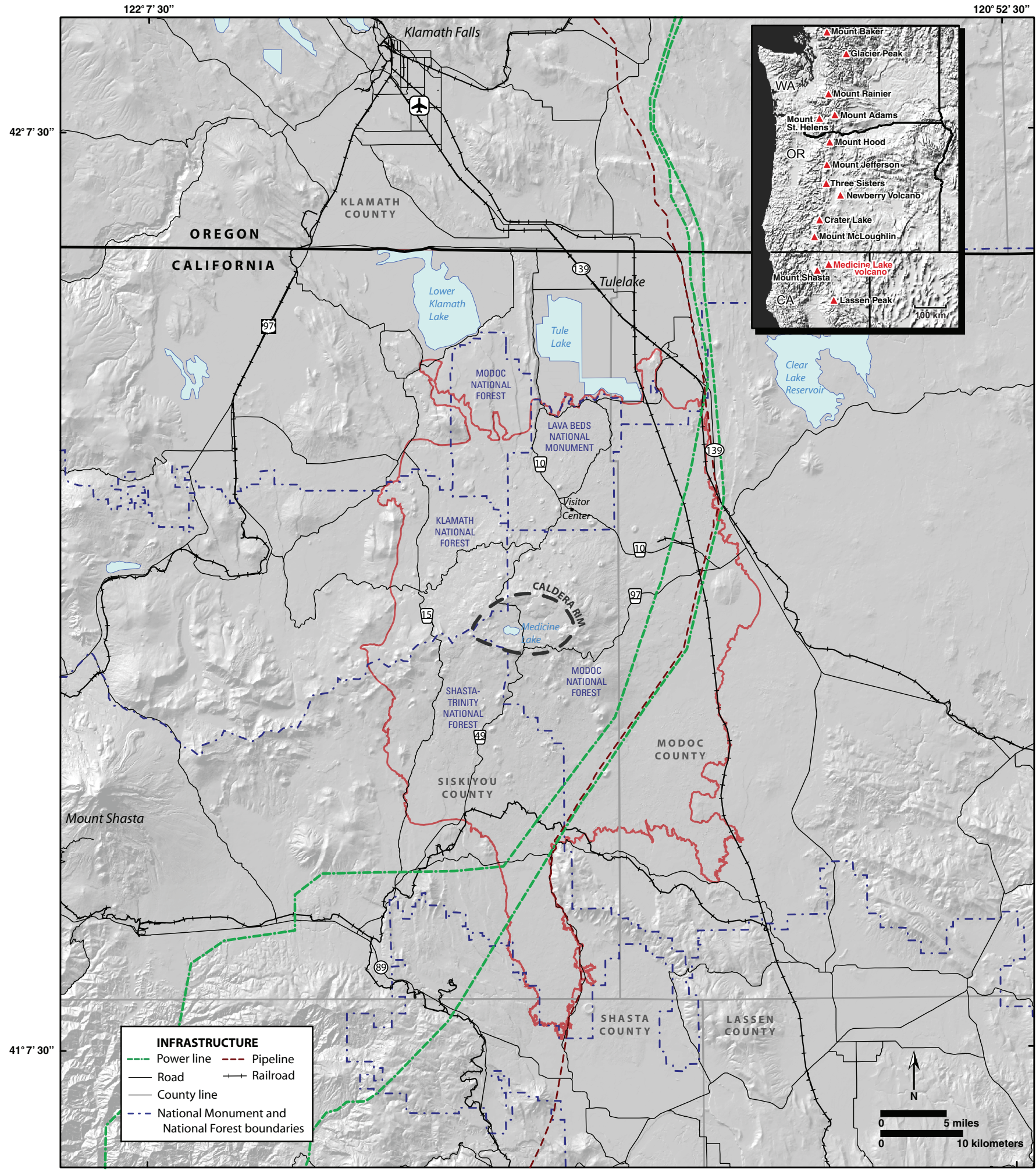

Figure 1. Map showing Medicine Lake volcano (red outline), land management boundaries and infrastructure information including roads (thin black lines) on shaded relief base. Inset map shows locations of major Cascade Range volcanoes (red triangles). 


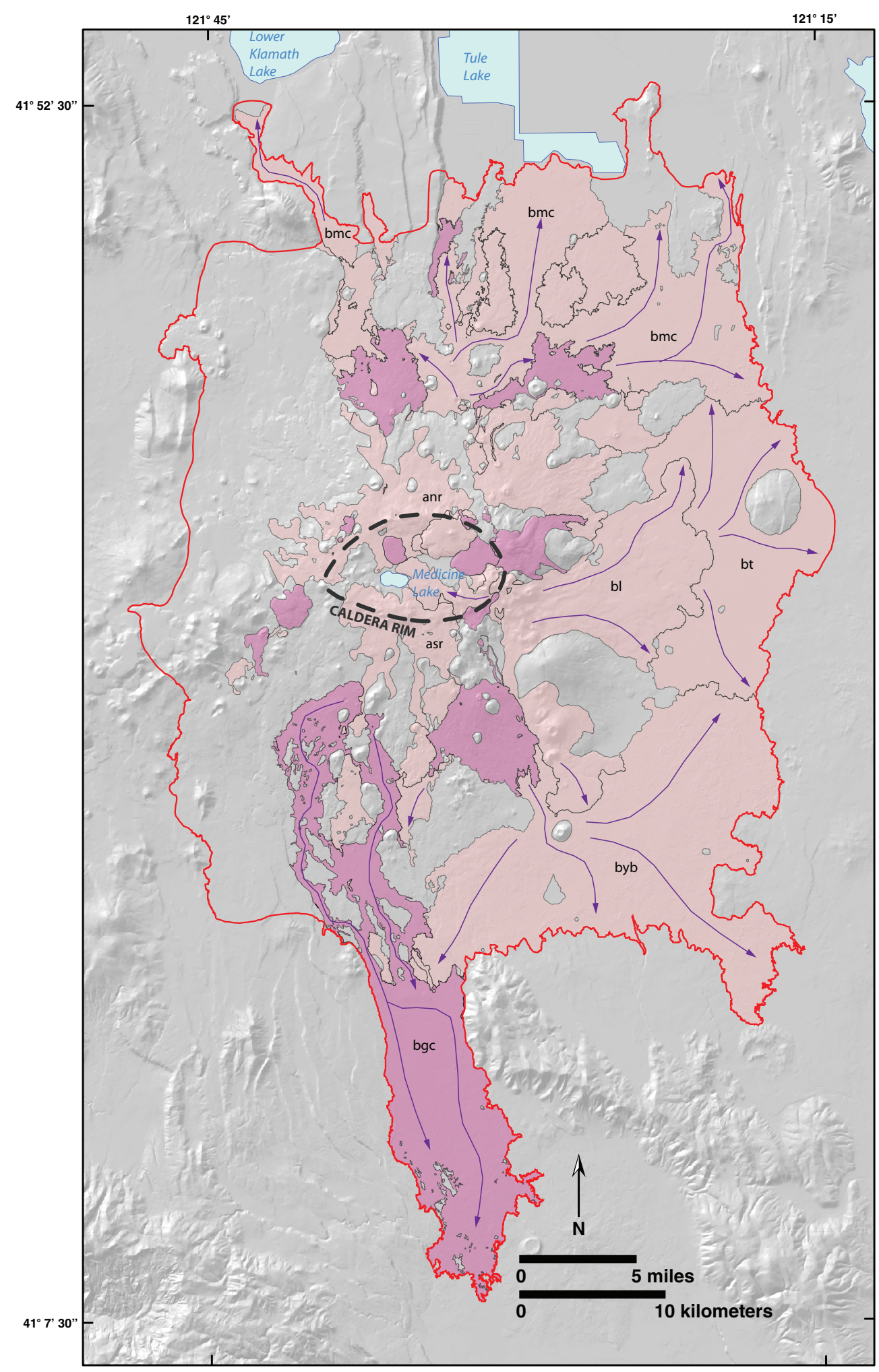

Figure 2. Map showing Medicine Lake volcano lava flows 100,000 years old and younger in shades of pink within red outline of the volcano. Postglacial lavas $\sim 13,000$ years old and younger are shown in darker pink. Major lava flows are labeled, including anr (andesite of north rim) and asr (andesite of south rim). Five very large basalt lava flows are also labeled: $b g c=$ basalt of Giant Crater, bmc = basalt of Mammoth Crater, byb = basalt of Yellowjacket Butte, $\mathrm{bl}=$ Lake Basalt, and $\mathrm{bt}=$ basalt of Tionesta. Flow directions are indicated by arrows on the five large basalt flows. 
silicic lavas, despite the limited exposure of such lavas at the surface (Donnelly-Nolan, 2006). Mafic lavas of basaltic to andesitic composition were also present in the volcano's early history, but they did not dominate until about 300,000 years ago, after which rhyolite eruptions were scarce until late Holocene time. However, a dacite episode about 200,000 to 180,000 years ago included emplacement of the volcano's only ash-flow tuff.

\section{Eruptive Activity from 100,000 Years Ago Until 13,000 Years Ago}

Approximately 100,000 years ago, compositionally distinctive silicic andesite and minor dacite built most of the present caldera rim, modifying the caldera that formed about 180,000 years ago. Eruption of these lavas was followed soon after by several large basalt flows, such that the combined area covered by eruptions between 100,000 years ago and postglacial time amounts to nearly half of the volcano's area (fig. 2). The estimated volume of MLV is $\sim 600 \mathrm{~km}^{3}$, largest of any volcano in the Cascade volcanic arc, with the possible exception of the very similar Newberry Volcano in central Oregon. The calculated overall effusion rate is $\sim 1.2 \mathrm{~km}^{3}$ per thousand years, although the rate for the past 100,000 years may be only half that.

Much of the present caldera rim consists of the andesites of the north rim and south rim, which erupted from a series of vents located over arcuate ring faults on the caldera margin. Subsequent to eruption of these rim andesites, 24 eruptions took place in late Pleistocene time before the postglacial activity that began about 13,000 years ago. Lavas from these two dozen eruptions cover $974 \mathrm{~km}^{2}$ (fig. 2). One reason for their extensive areal coverage is that they included 16 basalt eruptions, several of which produced significant volumes of fluid lava that spread across low topography adjacent to the volcanic edifice. These very large basalt flows include the largest lava flow known at MLV, the $300-\mathrm{km}^{2}$ basalt of Yellowjacket Butte (Donnelly-Nolan and others, 2005), which covered much of the southeast flank of the volcano about 85,000 years ago, soon after eruption of the $\sim 150-\mathrm{km}^{2}$ Lake Basalt and the $>140-\mathrm{km}^{2}$ of the (partially buried) basalt of Tionesta. Later, about 40,000 to 30,000 years ago, the basalt of Mammoth Crater spread across >225 $\mathrm{km}^{2}$ on the north side of the volcano, where it covers 70 percent of Lava Beds National Monument and areas well beyond the boundaries of the monument (fig. 2). Approximate flow paths of the largest basalt flows are shown on figure 2 . In all, the 16 basalt eruptions in this time period (100,000 to 13,000 years ago) covered $886 \mathrm{~km}^{2}$. One lowsilica dacite erupted early in the period and built much of the eastern rim of the caldera. The single rhyolite from this time drapes the northeastern caldera rim and has an age of about 30,000 years (Donnelly-Nolan and Lanphere, 2005). Its glaciated vent dome is named Mount Hoffman, and it forms the highest point on the volcano at 2,412 $\mathrm{m}$.

\section{Postglacial Eruptive Activity}

The timing and distribution of postglacial eruptions (fig. 3 , table 1), those since 13,000 years ago, are well understood (Donnelly-Nolan and others, 1990; Champion and others, 2005). This eruptive activity was strongly episodic (table 1) and also covered a disproportionately large area of $316 \mathrm{~km}^{2}$, almost 16 percent of the volcano's area, although spanning only 3 percent of the volcano's history. The 16 eruptions included in this interval took place from many vents scattered widely across the volcano in an area extending $\sim 35 \mathrm{~km}$ north-south and $\sim 20 \mathrm{~km}$ east-west. The eruptions began with an episode of seven basalt and basaltic andesite eruptions about 13,000 years ago. The extended north-south distribution of postglacial vents (fig. $3 A$ ) displays the influence of the overall east-west extensional tectonic environment. Much of the lava documented from this time period erupted about 12,500 years ago during the Giant Crater event (DonnellyNolan and others, 1991; Champion and Donnelly-Nolan, 1994) that covered about $200 \mathrm{~km}^{2}$ with $>4 \mathrm{~km}^{3}$ of basaltic lava. Nearly 8,000 years of quiescence followed this early mafic episode before three subsequent closely spaced eruptive episodes produced the nine late Holocene eruptions (Champion and others, 2005).

\section{Late Holocene Activity}

Medicine Lake volcano's record of nine eruptions in the past 5,200 years yields one of the highest rates of late Holocene eruptive activity in the Cascades. Two dacite eruptions took place in and adjacent to the caldera about 5,000 years ago. About 3,000 years ago, a basalt eruption occurred low on the north flank and an andesite erupted on the south flank. The most recent eruptive episode at MLV included five events spanning about 280 years between about 1,230 and 950 years ago, featuring compositions from basalt through rhyolite. The youngest of these eruptions formed the 950-year-old Glass Mountain flow (fig. 4). Silicic eruptions dominated late Holocene volcanism in both number of eruptions and volume, and they were focused near the caldera. Overall, since about 13,000 years ago, 20 percent of the $\sim 7.8 \mathrm{~km}^{3}$ erupted volume has been silicic. More rhyolite was erupted during late Holocene time than at any previous time at MLV since about 300,000 years ago.

\section{Magma Beneath the Volcano}

Geophysical evidence identified a small silicic magma body under the eastern part of the caldera (Evans and Zucca, 1988; Chiarabba and others, 1995). It is located at a depth of $3 \mathrm{~km}$ to as much as $7 \mathrm{~km}$ and has a volume of $10 \mathrm{~km}^{3}$ to a few tens of cubic kilometers. Experimental petrologic studies of the late Holocene rhyolites and of quenched mafic inclusions in Little Glass Mountain and Glass Mountain silicic 


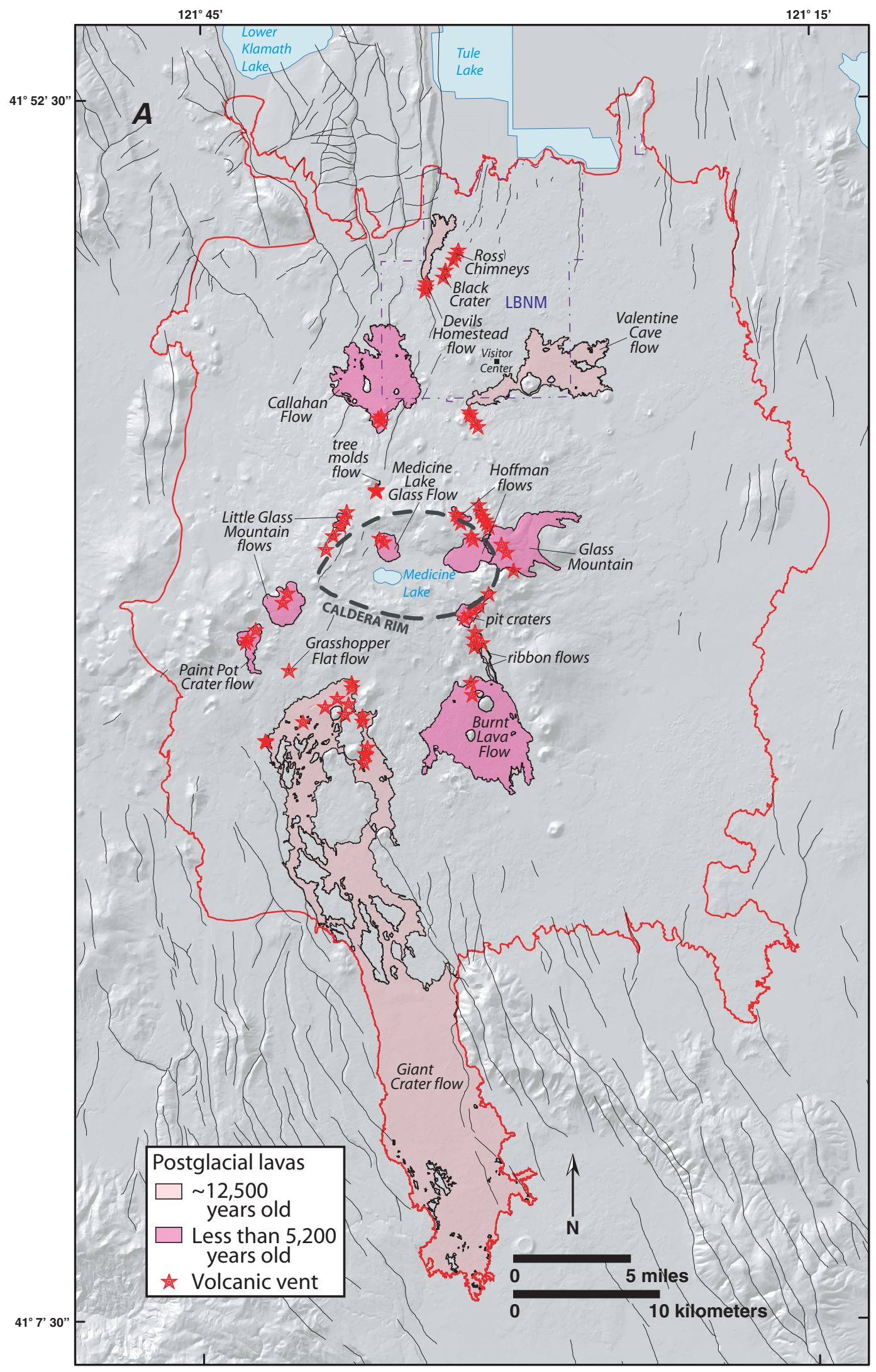

Figure 3. Map showing postglacial lava flows at Medicine Lake volcano, labeled by name as listed in table 1. Thin black lines are faults. LBNM is Lava Beds National Monument. Outline of Medicine Lake volcano in red. $A$, Flows divided by age groups. B, Flows divided by composition. 


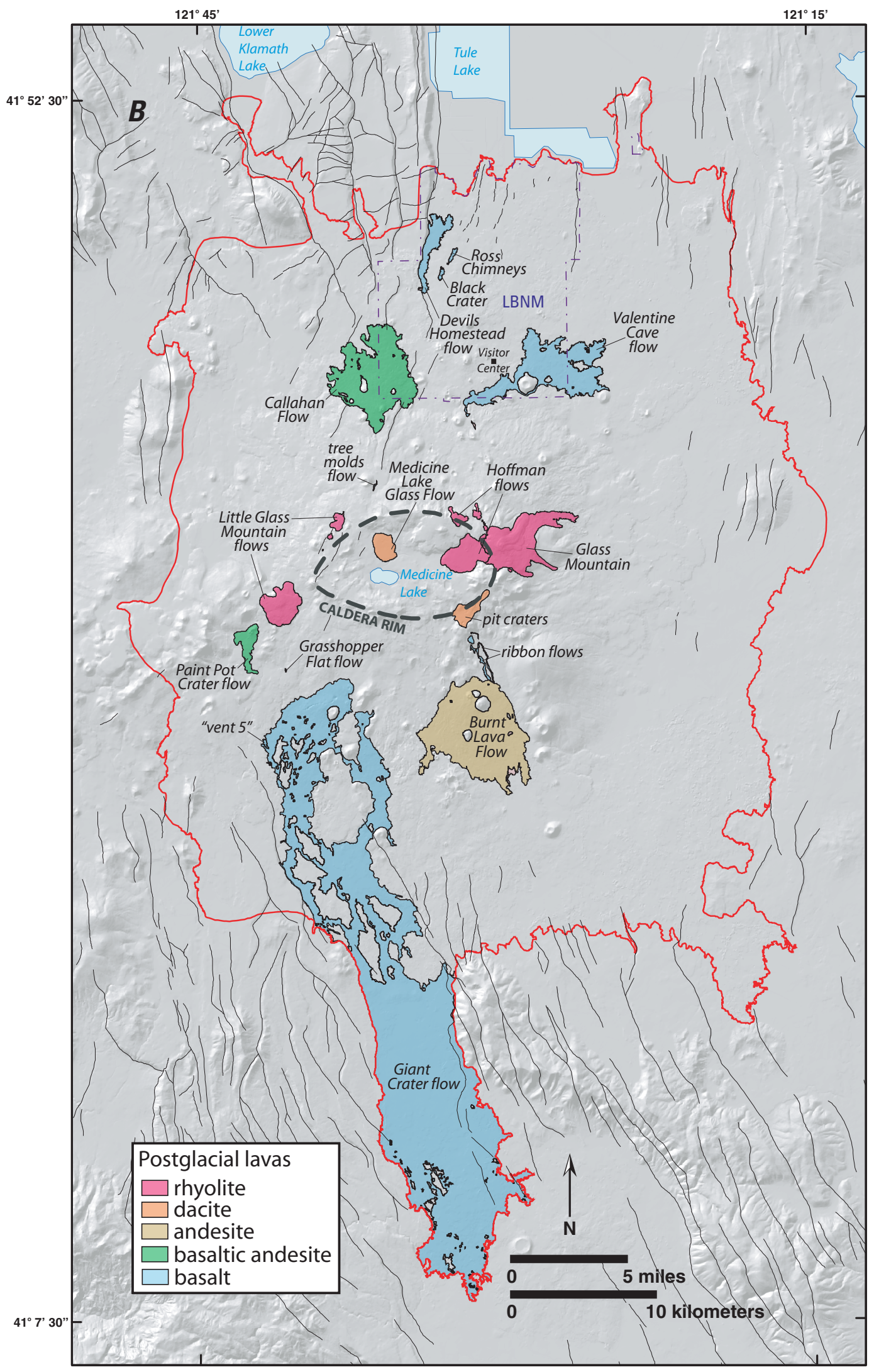

Figure 3.-Continued. 
Table 1. Chronology, area covered by lava flows and domes, and volume of postglacial eruptions at Medicine Lake volcano.

[BP, before present. By convention, present is A.D. 1950.]

\begin{tabular}{|c|c|c|c|}
\hline Postglacial eruptions & $\begin{array}{c}\text { Age } \\
\text { (cal. yr BP) }\end{array}$ & $\begin{array}{l}\text { Area } \\
\left(\mathbf{k m}^{2}\right)\end{array}$ & $\begin{array}{l}\text { Est. Volume } \\
\left(\mathrm{km}^{3}\right)\end{array}$ \\
\hline \multicolumn{4}{|c|}{ Episode 4} \\
\hline Glass Mountain & 890 & 14.0 & 1 \\
\hline Little Glass Mountain & 940 & 6.3 & 0.4 \\
\hline Paint Pot Crater flow & 1,110 & 2.7 & 0.04 \\
\hline Callahan Flow & 1,120 & 23.7 & 0.33 \\
\hline Hoffman flows & 1,170 & $\sim 8$ & 0.12 \\
\hline \multicolumn{4}{|c|}{ Episode 3} \\
\hline Burnt Lava Flow & 2,950 & 34.3 & 0.5 \\
\hline $\begin{array}{l}\text { Black Crater and Ross } \\
\text { Chimneys }\end{array}$ & 3,080 & 0.45 & 0.001 \\
\hline \multicolumn{4}{|c|}{ Episode 2} \\
\hline pit craters & 5,040 & 2.4 & 0.02 \\
\hline $\begin{array}{l}\text { Medicine Lake Glass } \\
\text { Flow }\end{array}$ & 5,140 & 2.4 & 0.08 \\
\hline \multicolumn{4}{|c|}{ Episode 1} \\
\hline Valentine Cave flow & 12,260 & 19.9 & 0.2 \\
\hline "vent 5" & 12,270 & 0.12 & 0.0002 \\
\hline Devils Homestead flow & 12,320 & 4.1 & 0.04 \\
\hline tree molds & 12,330 & 0.05 & 0.0001 \\
\hline Giant Crater flow & 12,430 & 198 & 4.35 \\
\hline ribbon flows & 12,480 & $\sim 8$ & 0.02 \\
\hline Grasshopper Flat & 12,490 & 0.02 & $<0.0001$ \\
\hline
\end{tabular}

lavas indicate crystallization at pressures equivalent to depths of 3 to $6 \mathrm{~km}$ (Grove and Donnelly-Nolan, 1986; Grove and others, 1997), in agreement with the magma depth indicated by the geophysical studies. Geologic models of MLV suggest a volcano built over a fundamentally basaltic magmatic focus consisting of a complex of dikes and derivative magma bodies (Donnelly-Nolan, 1988; Poland and others, 2006).

New basaltic intrusions into an existing magma body can add sufficient heat and volatiles to cause eruptions. The presence of quenched mafic inclusions in the most silicic late Holocene lavas indicates that mafic magma was intruded into the silicic magma reservoirs before eruption, thus documenting the presence of mafic magma that did not erupt to the surface. Petrologic studies by Grove and Donnelly-Nolan (1986) for Little Glass Mountain, by Grove and others (1988) for the Burnt Lava Flow (fig. 5), and by Grove and others (1997) for Glass Mountain document the variety and composition of the mafic inclusions and discuss the mineralogic and experimental evidence for multiple intrusions of parental mafic magma to generate the derivative magma that erupted to the surface.

\section{The Hydrothermal System}

No thermal springs emerge on the volcano, and only a single hot fumarole is present. Despite the paucity of such surface manifestations, drilling for geothermal energy has encountered a hydrothermal system beneath the upper part of the volcano.

Reported temperature measurements and alteration mineralogy indicate the presence of a high-temperature $\left(\sim 300^{\circ} \mathrm{C}\right)$ hot-water geothermal system (Hulen and Lutz, 1999; Bargar, 2001).

\section{Seismicity and Deformation}

Faults that emerge from the south side of MLV include the Mayfield Fault (fig. 6; Wills, 1991), which breaks the 12,500-year-old basalt of Giant Crater, creating $10 \mathrm{~m}$ of offset. There are obvious indications of Holocene faulting at MLV, including the multiple open ground cracks (fig. 7) that formed during eruption of the late Holocene rhyolite of Little Glass Mountain (Fink and Pollard, 1983). Similar large open cracks also apparently formed during eruption of the late Holocene basalt of Black Crater and Ross Chimneys (Donnelly-Nolan and Champion, 1987). However, documented historic seismicity at the volcano is rare (Dzurisin and others, 1991). In part, the lack of documented seismicity may be a result of the lack of instrumentation and the short period of time since seismometers were first installed on the volcano in 1980. However, large earthquakes would have been detected by seismic stations located outside the area. There is also the possibility that extensional events and accompanying seismicity may be episodic and the volcano is currently in an interval between episodes.

A swarm of earthquakes, the largest a magnitude 4.1, occurred at shallow depth under Medicine Lake caldera in late September, 1988, followed by smaller events in subsequent months. The events were interpreted as tectonic, not volcanic earthquakes (Walter and Dzurisin, 1989). Two long-period (LP) earthquakes have been detected under the volcano, possibly indicating magma migration at depth (Pitt and others, 2002). Seismic monitoring of the volcano has not been continuous, so additional LP events could have occurred without being detected.

Earthquakes have also occurred in the nearby region. Two swarms of earthquakes with maximum magnitude 4.6 took place about $25 \mathrm{~km}$ west of Medicine Lake, halfway between MLV and Mount Shasta, in 1978 and 1981. The 1978 swarm, called the Stephens Pass earthquakes (Bennett and others, 1979), had a maximum magnitude of 4.6, and the earthquakes were accompanied by ground breakage. Maximum magnitude of the 1981 Tennant swarm, about $10 \mathrm{~km}$ north of Stephens Pass, was 4.1 (Dzurisin and others, 1991). To the north of MLV, along the projection of faults that emerge from under the north side of the volcano, an earthquake swarm took place in 1993 on faults west of Klamath Falls. The two largest events were magnitude 6.0 , indicating that damaging earthquakes can occur in the region. 


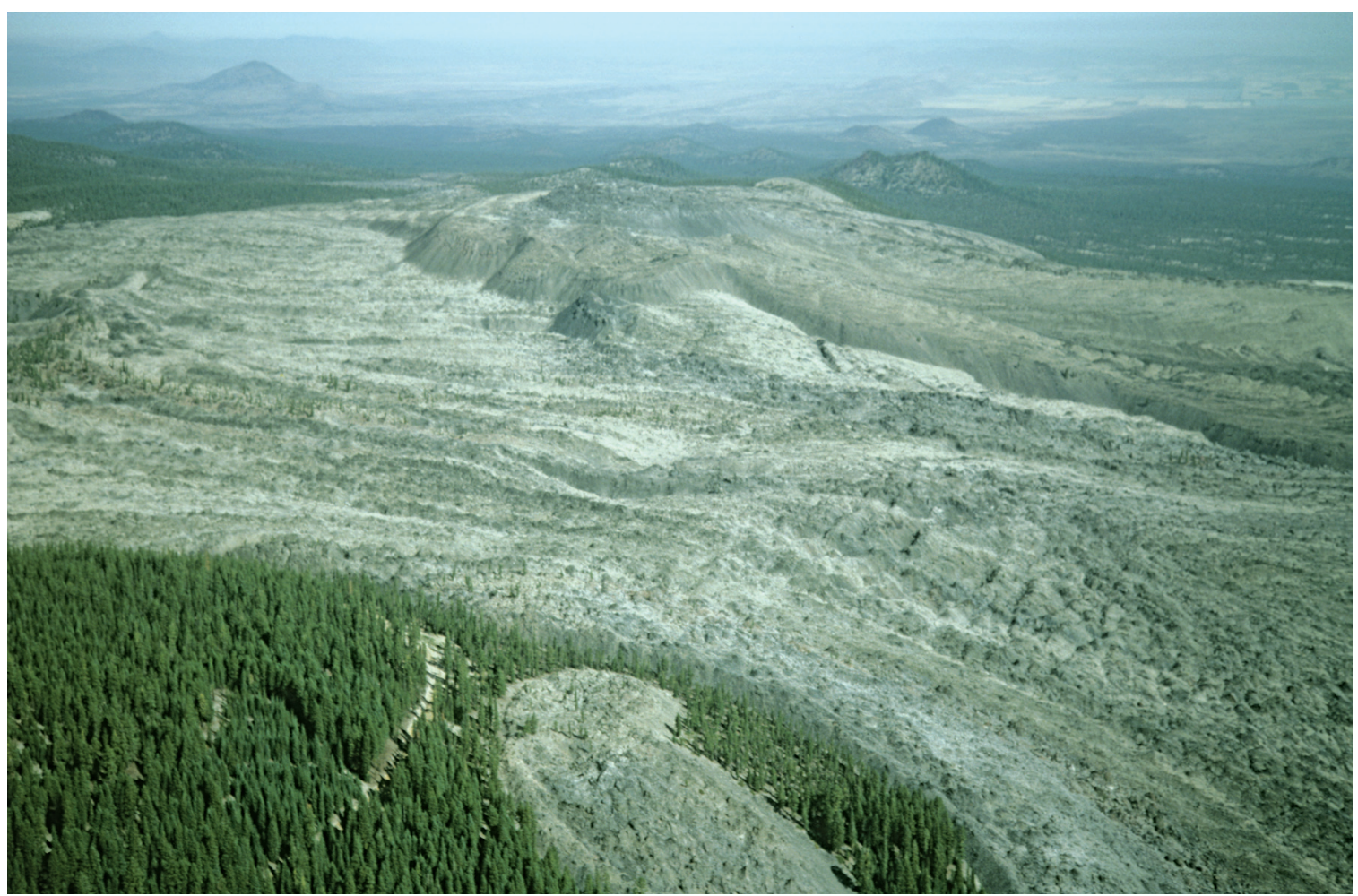

Figure 4. View of Glass Mountain, looking north. In the foreground is the southernmost rhyolite dome along the north-northwest-trending fissure that fed the main Glass Mountain flow and 10 additional domes to the north. This most recent eruption at Medicine Lake volcano occurred about 950 years ago.

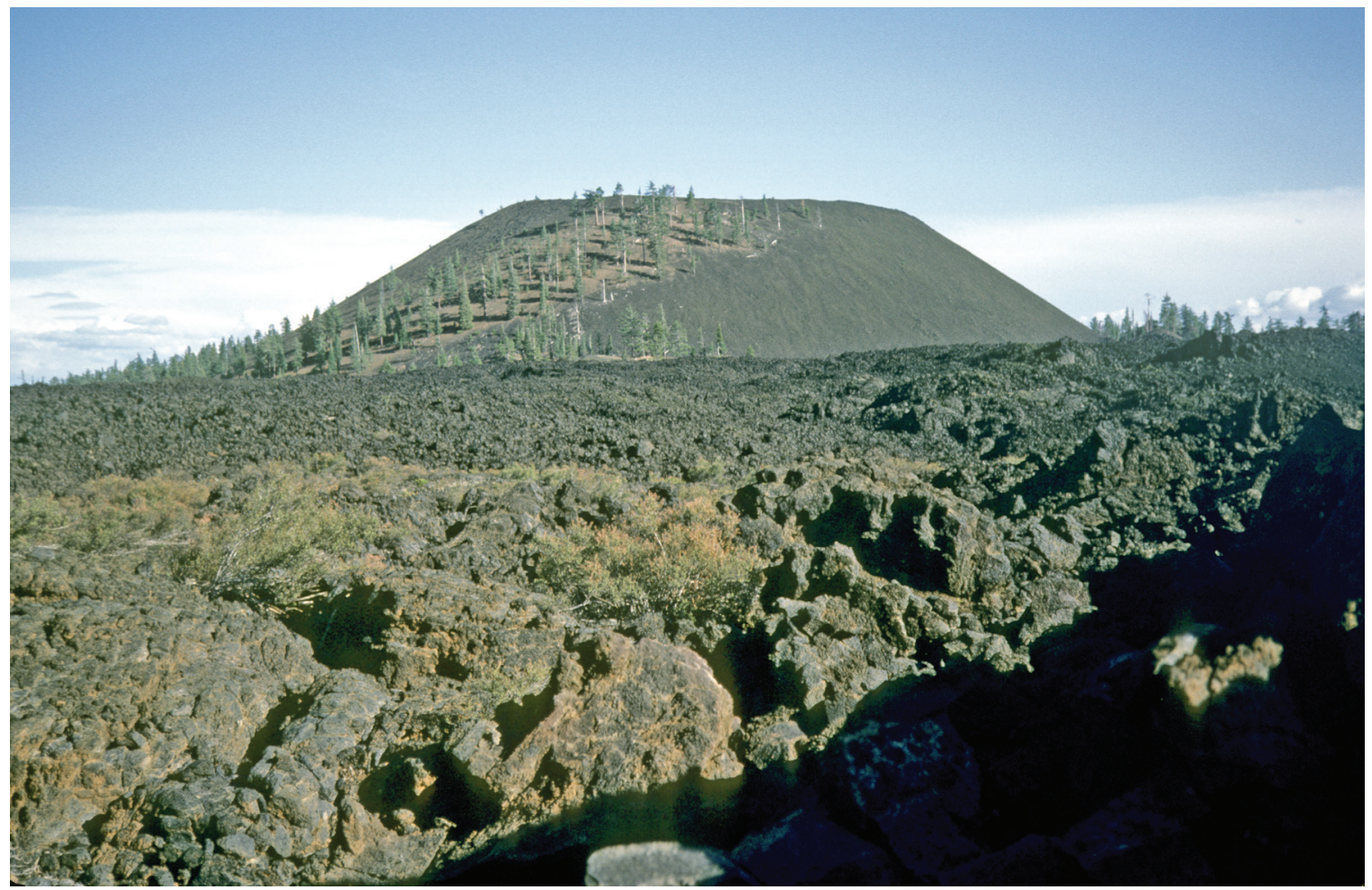

Figure 5. Burnt Lava Flow and its principal vent, the 120-m-high cinder cone named High Hole Crater. Erupted about 3,000 years ago, this is one of the youngest cinder cones at Medicine Lake volcano. Cinder cones are abundant at the volcano and are widely scattered across the edifice. 
Dzurisin and others (2002) have shown that the center of the MLV caldera is currently subsiding with respect to the outer margin of the volcano at the rate of $8.6 \mathrm{~mm} / \mathrm{yr}$. The rate is $4.9 \mathrm{~mm} / \mathrm{yr}$ for subsidence of the center of the caldera relative to the caldera rim. This rapid rate of subsidence is too high to be sustained for thousands of years and is undoubtedly temporary. The overall subsidence is explained as a combined result of east-west regional extension and the weight of the large edifice itself over a hot, weak crust (Dzurisin and others, 1991, 2002) combined with the cooling of hot rock beneath the volcano (Poland and others, 2006).

\section{Discussion of Volcano-Related Hazards}

\section{Lava Flows and Domes}

Mafic lava flows and associated cinder cones (fig. 5) and spatter cones are the dominant eruptive phenomena at the volcano. Such eruptions could occur anywhere on the volcano, and lava could potentially erupt from multiple vents distributed along fissures as long as $15 \mathrm{~km}$. More than 80 eruptions of basalt have taken place during the history of the volcano, as well as approximately 60 eruptions of basaltic andesite and nearly 40 of andesite. Andesite and basaltic andesite lava flows are typically limited in length to $<12 \mathrm{~km}$, cover areas less than $25 \mathrm{~km}^{2}$, and have volumes less than $0.5 \mathrm{~km}^{3}$. Basalt flows range in size from very small $\left(<0.01 \mathrm{~km}^{2}\right)$ to very large $\left(>300 \mathrm{~km}^{2}\right)$. Very large basalt eruptions can begin with basaltic andesite, but a decrease in silica content as the eruption progresses, along with formation of one or more lava tubes, could indicate a long-term large eruption.

The largest basalt flows at MLV erupted during the most recent fifth of the volcano's existence. They are identified and shown with arrows indicating generalized flow paths on figure 2 . The youngest of these very large basalt flows is the postglacial, 12,500-year-old Giant Crater flow (Donnelly-Nolan and others, 1991), which covers about $200 \mathrm{~km}^{2}$. It flowed 45 km south from its vents on the volcano's south flank (fig. 3). Eruptions such as that probably continue for months or years. One estimate of the time span of the Giant Crater eruption is approximately a decade (Champion and Donnelly-Nolan, 1994), but comparison to the ongoing, quarter-century-long eruption at Kilauea Volcano in Hawaii suggests that multiple decades could elapse during such an eruption. The broad apron formed by the extensive basalt flows establishes a perimeter that is not likely to be exceeded by future flows. Nonetheless, it is possible that a future basalt flow could advance beyond this limit, and an extended lava flow hazard zone is shown on figure 8 and on plate 1. If lava should flow into Tule Lake, localized explosive activity would occur where hot lava meets water.

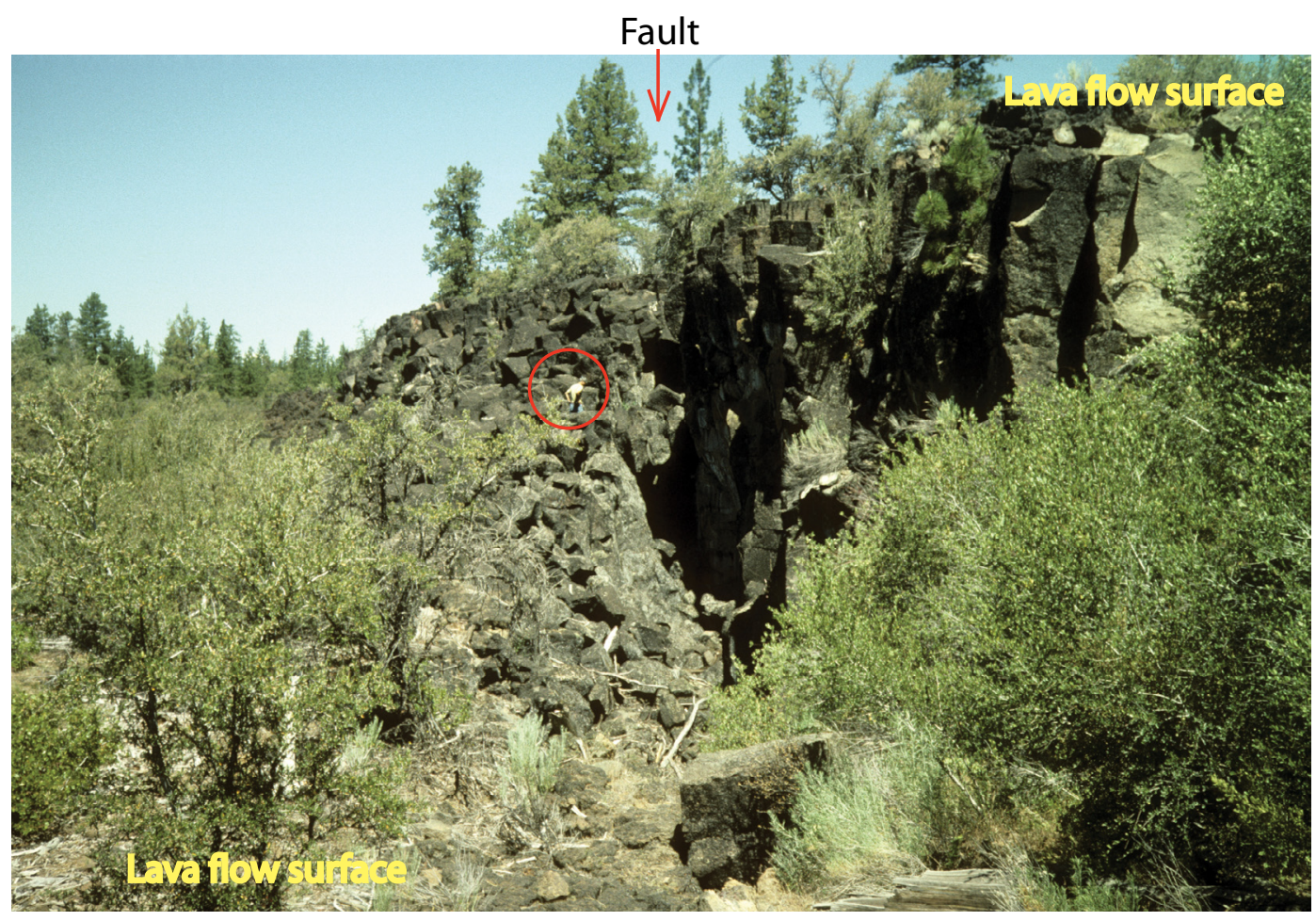

Figure 6. The Mayfield Fault (Wills, 1991) breaks the 12,500-year-old Giant Crater lava flow, creating a 10 -m-high scarp. Person (circled for scale) is on portion of lava flow that has been tilted by faulting; view is to the north. About $10 \mathrm{~m}$ out of view to the right, on the upfaulted portion of lava flow, a pair of buried gas pipelines that carry natural gas from Canada to California run parallel to the fault. Farther north, the power lines that carry electricity between the Pacific Northwest and California cross the fault. 


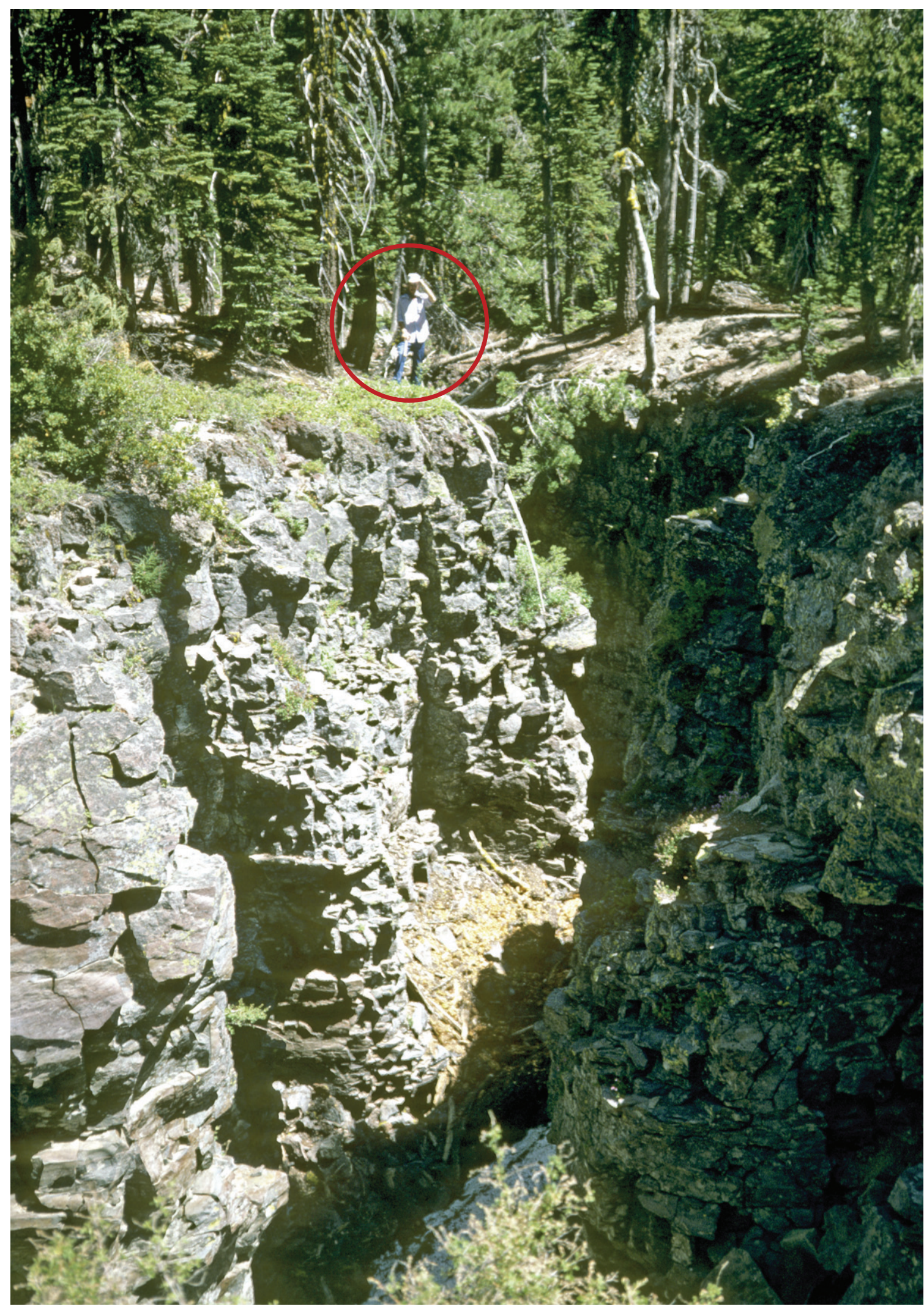

Figure 7. Large open ground cracks that apparently formed about 1,000 years ago during the fissure eruption of Little Glass Mountain rhyolite. Person is circled for scale; view is to northeast. Walls of the crack fit back together in east-west direction. 
Silicic lava flows are only likely to occur high on the volcano and cover relatively small areas, although eruptive fissures for the late Holocene Little Glass Mountain and Glass Mountain eruptions were 8 and $5 \mathrm{~km}$ long, respectively. The Glass Mountain lavas cover about $14 \mathrm{~km}^{2}$. The viscous nature of silicic lava and documented eruptive rates at volcanoes such as Mount St. Helens indicate that years to decades could elapse during such an eruption.

The most likely future volcanic event at MLV would be a mafic eruption that built a cinder cone and produced a lava flow a few kilometers in length. However, prolonged silicic or basaltic eruptions lasting years or even decades are possible. Lava flows are not likely to advance rapidly enough to overtake fleeing individuals, but they would damage or destroy any infrastructure in their path, including structures in Lava Beds National Monument and(or) the power lines (fig. 1) that cross the eastern and southern flanks of the volcano. Extensive basalt flows could conceivably also damage or destroy compressor stations along the natural gas pipeline, but such an occurrence is extremely unlikely. During dry or windy weather, the advancing flow front of any lava flow on the volcano would likely cause fires.

Regional basaltic volcanism outside the lava flow hazard limit drawn on plate 1 is possible, but unlikely. To the west, between MLV and Mount Shasta, is a broad area of Pleistocene volcanism, but no postglacial eruptions are known there. To the east of MLV, one basaltic eruption took place about 140,000 years ago. To the south, the late Pleistocene Brushy Butte basalt flow is located in the gap between MLV and the Lassen Volcanic Center.

\section{Airborne Ash and Tephra Fallout Hazards}

Tephra accompanying silicic eruptions could be regionally widespread if the eruption column rises several kilometers into the air, as would be likely. The fallout could cause short-term disruption of activities in Klamath Falls if the wind direction took volcanic ash to the north. Local communities, Lava Beds National Monument, roads and highways, and the utility corridor that crosses the east and south sides of the volcano would probably be affected for days or weeks. Tephra produced by explosions early in the Glass Mountain eruption about 950 years ago deposited pumice and ash several meters thick near the vents (fig. 9), but the deposit thins rapidly to $<1$ $\mathrm{cm}$ some $40 \mathrm{~km}$ to the northeast. The tephra fallout volume for this eruption, based on thickness contours in Heiken (1978), is $0.27 \mathrm{~km}^{3}$ using the method of Fierstein and Nathenson (1992). Using the same method and the thickness contours published by Heiken, tephra erupted at Little Glass Mountain is calculated to have a fallout volume of $0.12 \mathrm{~km}^{3}$. Despite typical dominant westerly wind directions (fig. 10), this latter eruption had a southwest-directed plume depositing the most distal fragments on the slopes of Mount Shasta (found by D. Miller, as reported in Heiken, 1978).

The volume of tephra ejected from Mount St. Helens on May 18, 1980, is calculated to be $1.12 \mathrm{~km}^{3}$ (Fierstein and
Nathenson, 1992). Known tephra eruptions are poorly represented at MLV, possibly because exposures are poor. Tephras were not recovered during drilling of the geothermal exploration holes, in which few are recorded. Figure 11 shows the current estimated annual probability (in percent) of $1 \mathrm{~cm}$ or more of tephra accumulation from any major Cascade volcano. At MLV there is a 1 in 5,000 chance of $1 \mathrm{~cm}$ of tephra falling in any given year. Although $1 \mathrm{~cm}$ of ash may seem a very small amount, experience with Mount St. Helens eruptions indicates that as little as $0.5 \mathrm{~cm}$ of ash is sufficient to slow vehicle traffic to a crawl and to close businesses for as much as a week or two. Near-vent accumulations of tephra could be many meters thick, but no permanent habitations exist at MLV close to likely silicic vent locations. As much as $30 \mathrm{~cm}$ of combined tephra from the Little Glass Mountain and Glass Mountain eruptions is found in the southwestern corner of Lava Beds National Monument, but only a few centimeters are present at the visitor center only about $8 \mathrm{~km}$ farther northeast.

Aircraft could be affected by any eruption that generated tephra, although mafic eruptions are much less likely than silicic eruptions to produce large volumes of tephra. Numerous mafic cinder cones dot the broad surface of MLV, indicating explosive activity at these vents. Eruption columns associated with cinder cone formation can rise several kilometers into the atmosphere (for example, Hill and others, 1998). Close to the vents, volcanic bombs and scoria would be deposited, with ash depositing as much as a few kilometers away. Close to the vent(s), these mafic ash deposits could be several meters thick, but such deposits typically thin quickly away from their vents.

\section{Medicine Lake Caldera and Associated Hazards}

Medicine Lake (fig. 12) is the largest body of water on the volcano - other than a few very small lakes, a single short creek, scarce water holes, and rare springs, the volcano lacks other surface water. This 1x2-km caldera lake (Childs and others, 2000) and adjacent area are popular for camping and boating during summer months, and private cabins border parts of the lake. Holocene eruptive activity in and near the caldera (fig. 13 ) includes two dacite eruptions that took place approximately 5,000 years ago, as well as three rhyolite lava flows and accompanying tephras between about 1,230 and 950 years ago.

According to Mastin and Witter (2000), 610 of the 7,900 total Holocene eruptions on Earth have taken place through lakes or seawater. If a volcanic vent were to open under Medicine Lake, the eruption would almost certainly be accompanied by phreatomagmatic eruptions that would deposit wet, muddy tephra over the immediate area, including the campgrounds and cabins, and perhaps over much of the caldera (see the phreatomagmatic hazard zone limit on fig. 13 and plate 1). More dangerous, in the unlikely event that it should occur, would be a pyroclastic base surge forming at the base of an eruption column. Such surges commonly extend as much as a few crater diameters from the eruptive vent, but may extend in either the upwind or downwind direction (Waters and Fisher, 1971; Lorenz, 2007). Surges are turbulent 


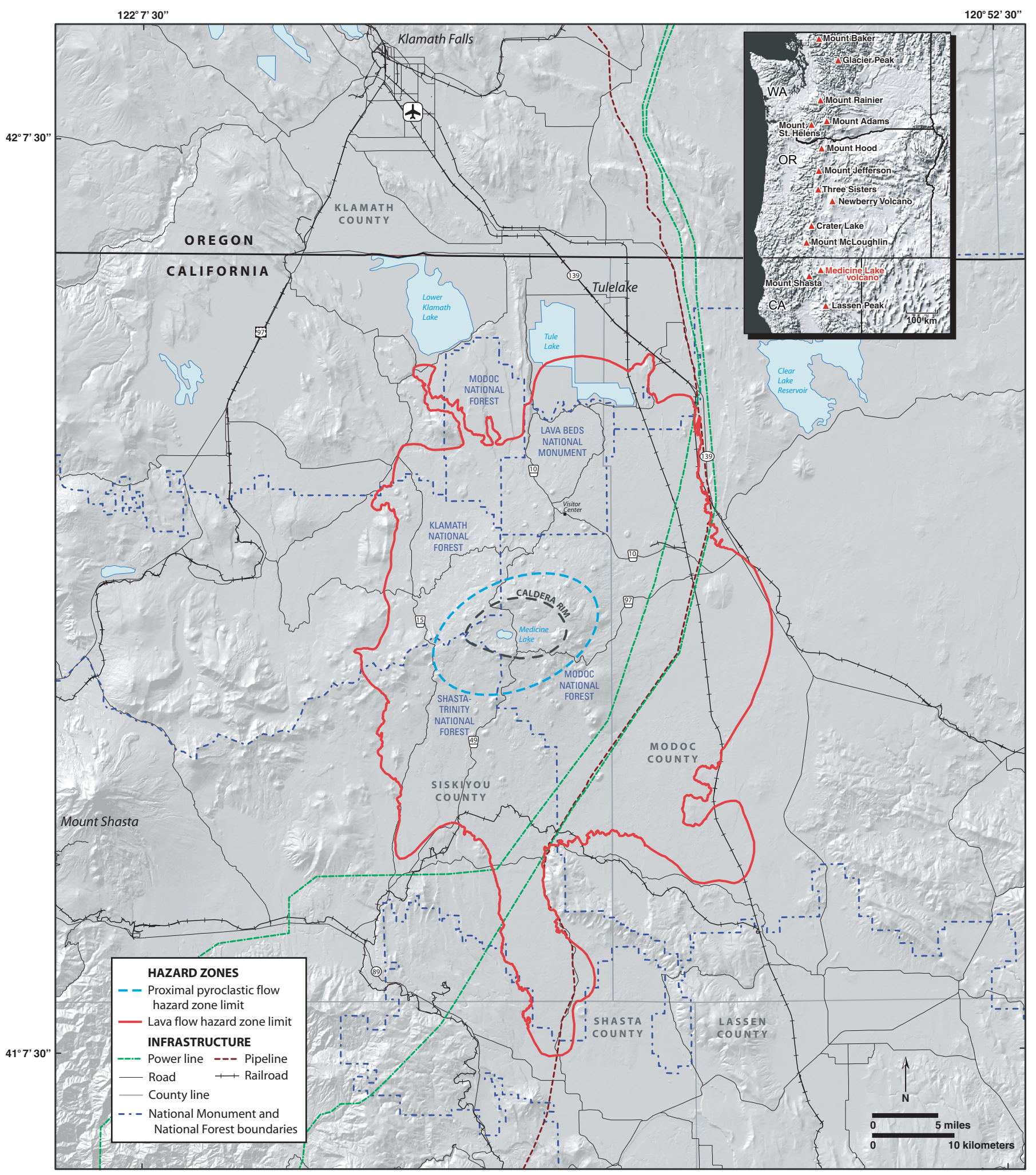

Figure 8. Hazard zonation map of Medicine Lake volcano, showing county and land-management boundaries and infrastructure, including major power lines that carry electric power between the Pacific Northwest and California and the major pipeline that carries natural gas from Canada to California. Inset map shows major Cascade Range volcanoes (red triangles). Both maps are on shaded relief base. 


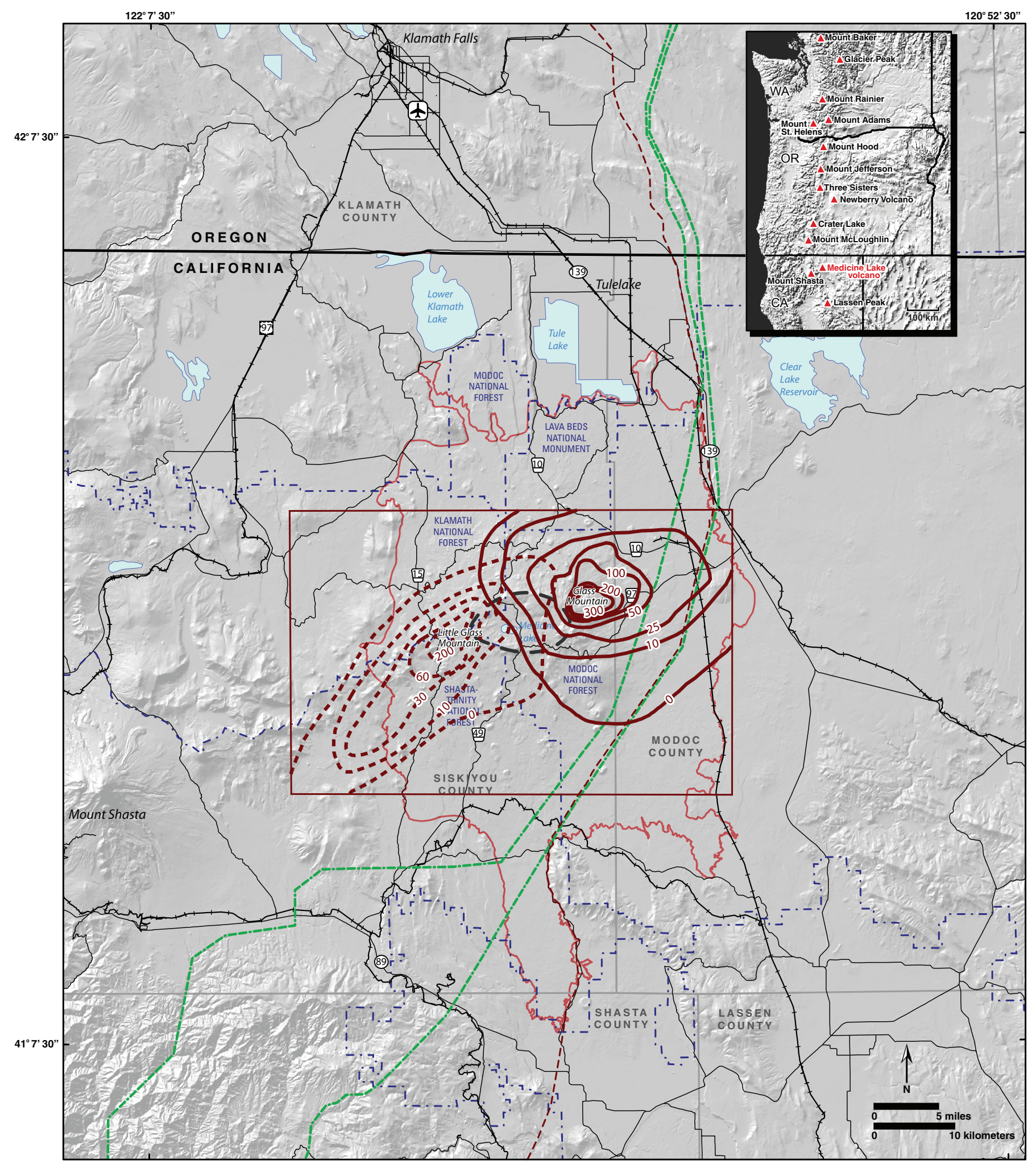

Figure 9. Isopach map (from Heiken, 1978) showing thickness contours in centimeters of Little Glass Mountain tephra (dashed lines) and Glass Mountain tephra (solid lines). Area of Heiken's map is outlined by brown rectangle. Glass Mountain tephra extends an undetermined distance to the northeast. Contour labeled "0" is Heiken's assessment of the "minimum measurable thickness." See figure 1 for explanation of base map. 

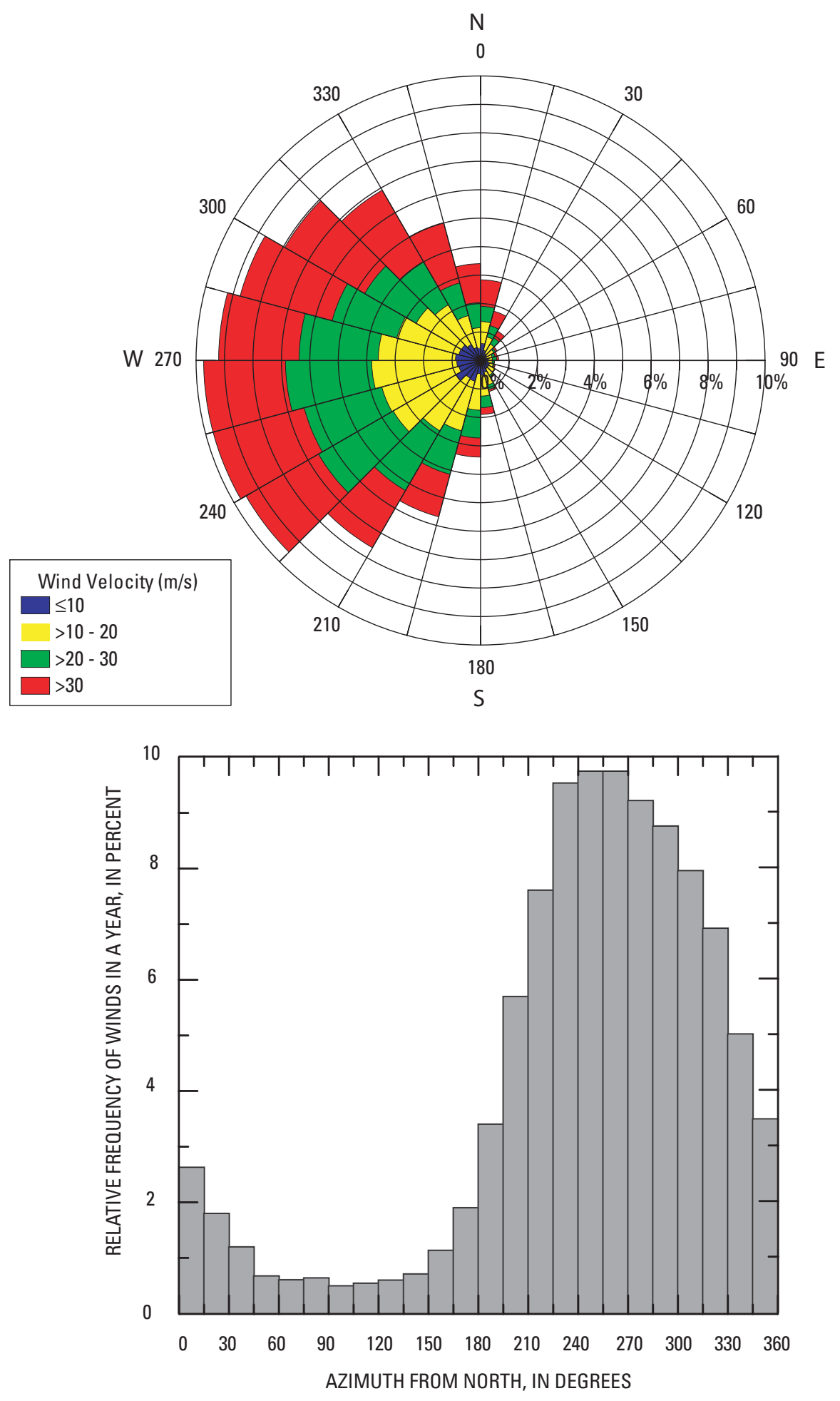

DIRECTION WIND BLOWS FROM

Figure 10. Rose diagram (top) and histogram (bottom) showing directions from which winds blow in the vicinity of Medicine Lake volcano. Rose diagram also shows relative frequencies of wind speeds at an elevation of 9,360 m. Data from 1997-2006, comprising 14,608 data points from NOAA-ARL final archive (http://www.arl.noaa.gov/ready-bin/fnl.pl , last accessed August 15, 2007). 
steam-driven mixtures of hot gas and volcanic rock fragments that can move along the ground surface at speeds of $100 \mathrm{~m} /$ sec. They can destroy everything in their path.

Intrusion of magma into the shallow hydrothermal system that has been identified beneath the caldera by geothermal exploration drilling could also lead to phreatic (steam) eruptions at the surface. Steam explosions have accompanied intrusion at hydrothermal systems in New Zealand (Nairn, 1979) and have occurred at several other volcanoes, sometimes preceding larger magmatic eruptions (Lipman and Mullineaux, 1981; Mastin, 1991; Wolfe and Hoblitt, 1996; Zlotnicki and others, 1992).

Both intrusion and extrusion of magma could be accompanied by faulting, such as the large open ground cracks (fig. 7) that accompanied emplacement of the rhyolite of Little Glass Mountain about 1,000 years ago (Fink and Pollard, 1983). Faulting and(or) hydrothermal explosions, whether accompanied by extrusion of magma or not, could allow magmatic gases such as carbon dioxide, sulfur dioxide, and hydrogen sulfide to reach the surface. During periods of extended calm wind conditions, toxic gases could accumulate in closed low areas of the caldera within about $12 \mathrm{~m}$ vertically from the lake surface, potentially resulting in asphyxiation of anyone at or near the lake (see the gas hazard zone limit on fig. 13 and plate 1).

The probability of an eruption within Medicine Lake caldera at a time when people are present is extremely low, but it must be remembered that the caldera is located over the center of the broad magmatic focus that has created and maintained the volcano over the past half million years. At least five eruptions in the last 5,200 years have directly affected the caldera, and the presence of Medicine Lake itself, together with the underlying hydrothermal system and the enclosed topographic basin, all combine to increase the hazard beyond that of a flank eruption. A lava flow within

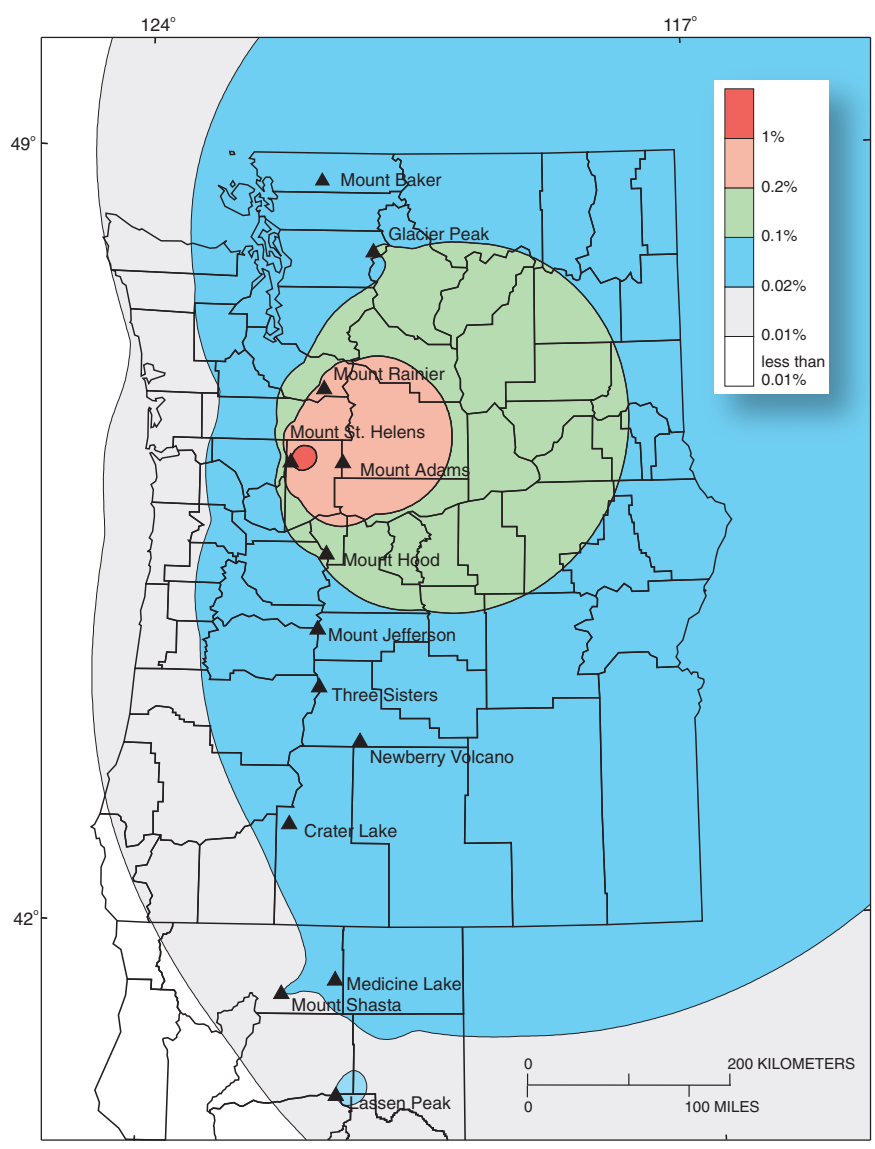

Figure 11. Map showing annual probability of $1 \mathrm{~cm}$ or more of tephra accumulation from any major Cascade volcano (black triangles), including Medicine Lake volcano (Gardner and others, 1995, using the method of Hoblitt and others, 1987). The Medicine Lake area has one chance in 5,000 each year of receiving $1 \mathrm{~cm}$ or more of tephra. Black lines are state and county boundaries.

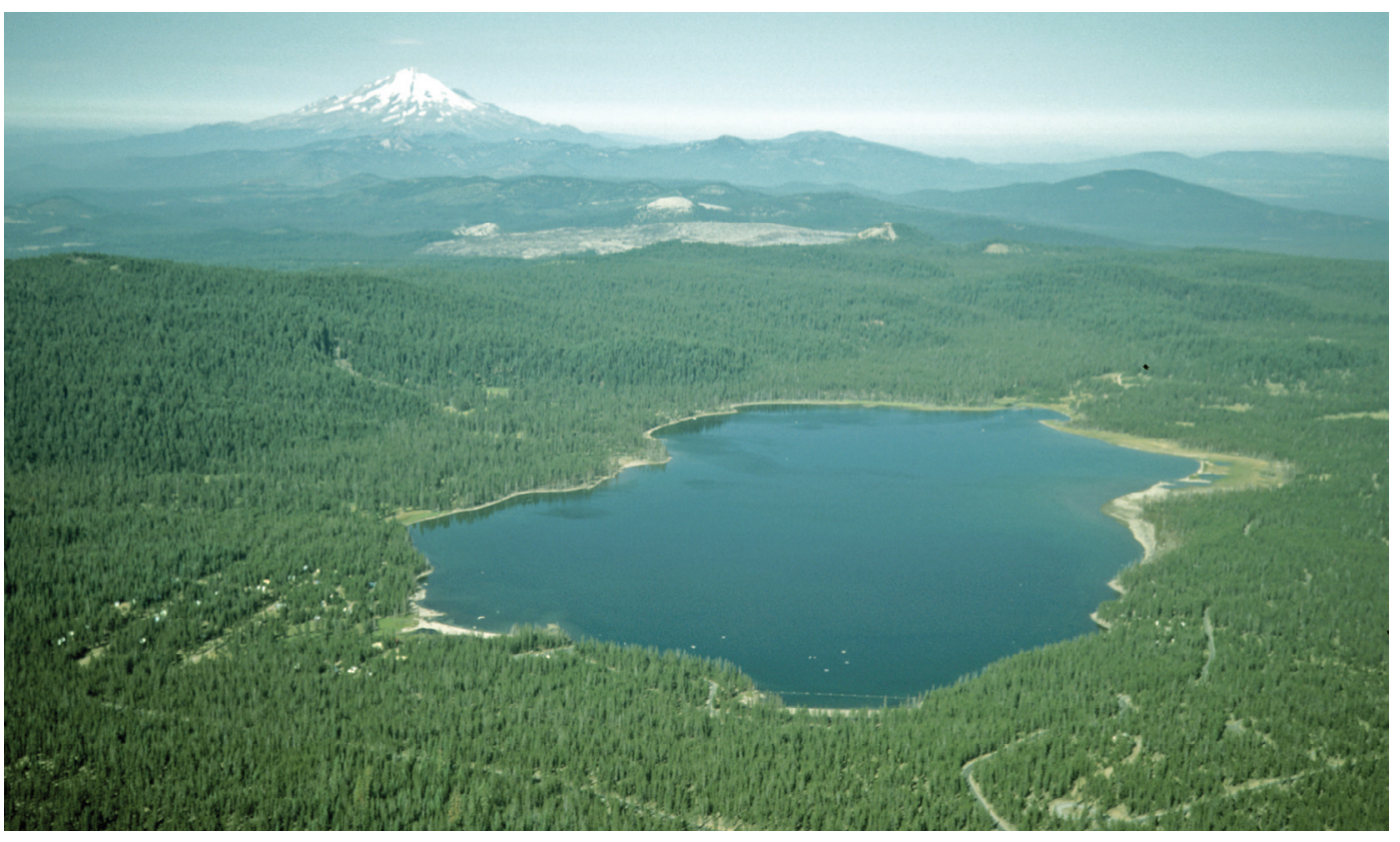

Figure 12. Aerial view looking west across Medicine Lake toward Mount Shasta on the horizon. The lake is approximately $1 \mathrm{~km} \times 2 \mathrm{~km}$. Some of the private cabins located on the south side of the lake can be seen in the lower left portion of the photo; campgrounds are located on the north shore of lake (right-hand side in photo). Late Holocene Little Glass Mountain flow is in middle distance (gray area). 


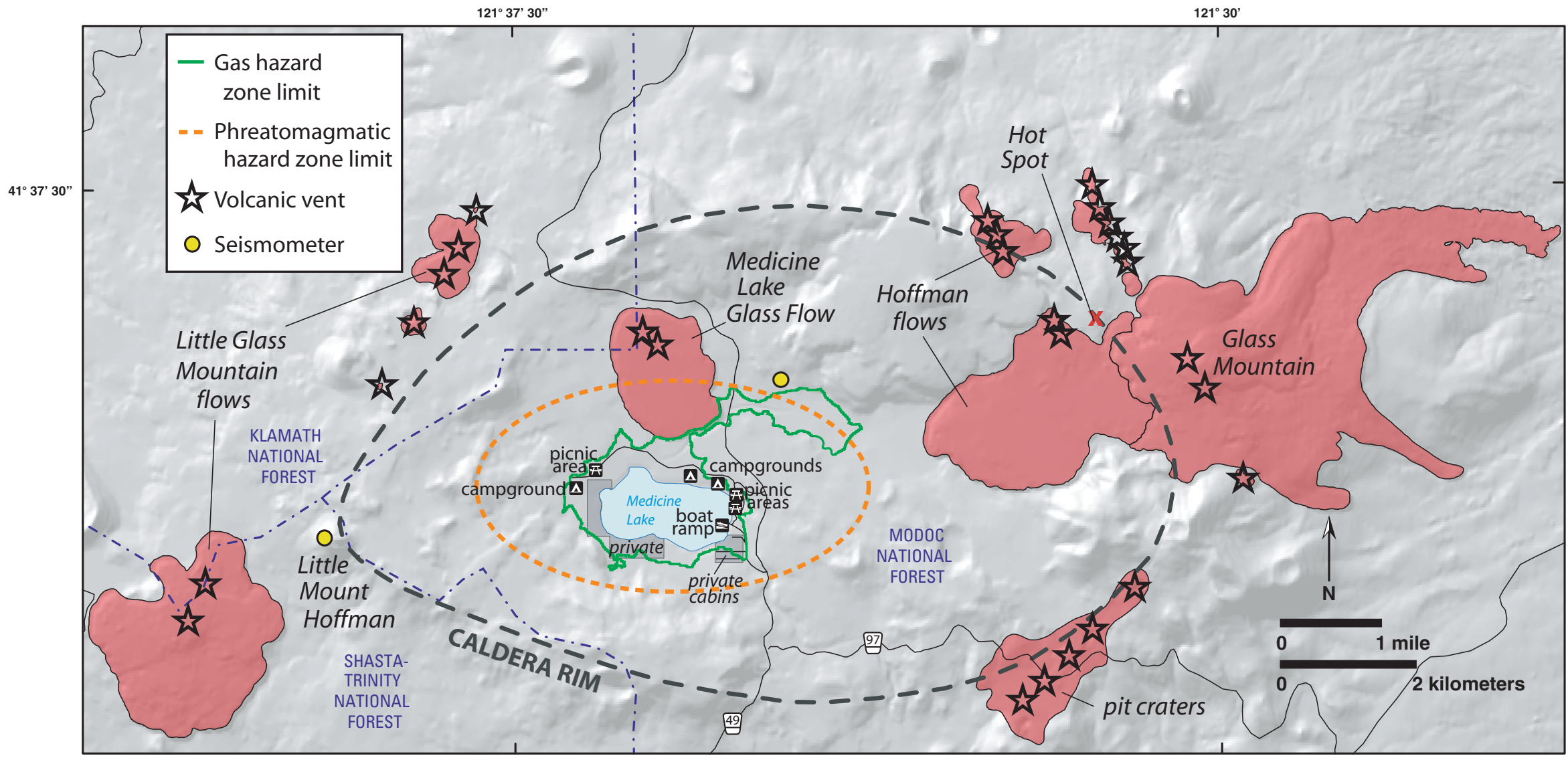

Figure 13. Map showing caldera features and caldera-related hazards at Medicine Lake volcano. Green line (gas hazard zone limit) indicates elevation contour that defines the closed basin within the caldera, including Medicine Lake. This is the area within which volcanic gases heavier than air could accumulate and potentially result in asphyxiation for anyone within the zone. Orange dashed line (phreatomagmatic hazard zone limit) indicates likely extent of phreatomagmatic deposits of hot volcanic mud should a volcanic vent open under the lake. Lava flows shown in red are 5,200 years old and younger. Hot Spot (red " $x$ ") is site of the volcano's only fumarole. 
the caldera could potentially impinge on the lake, generating localized steam explosions. If snow were present, an eruption on the caldera rim, or possibly hot tephra deposited on the rim, could melt the snow and generate lahars, although they would likely be small in extent. Intracaldera lahars could travel down the steep inner walls of the caldera, but few or no people would be affected by such a wintertime event. Small pyroclastic flows (see below) could accompany emplacement of silicic flows and domes.

\section{Pyroclastic Flows}

Small local pyroclastic flows (hot, rapid flows consisting of mixtures of gas, pumice, and rock fragments) could occur on the upper parts of the volcano during emplacement of silicic lava flows similar to Glass Mountain and Little Glass Mountain. The proximal pyroclastic flow hazard zone limit drawn on figure 8 and on plate 1 assumes that most silicic eruptions would be located near the center of the volcano and that associated pyroclastic flows would likely travel only short distances, probably $1 \mathrm{~km}$ or less, from the vents or collapsing flow fronts. An eruption generating large pyroclastic flows is extremely unlikely, although not unprecedented at MLV. One such eruption took place at the center of the volcano about 180,000 years ago, creating a summit caldera and feeding highly mobile, hot, volatile-rich pyroclastic flows down the flanks of the volcano. Any such eruption would destroy everything in its path, but the probability of such a high-consequence event is considered negligible.

\section{Seismicity and Faulting}

Ground shaking and fault movements accompanying volcanism are not likely to cause serious problems over most of the volcano, but locally rockfalls could occur on steep slopes. Such rockfalls from the south caldera wall could endanger cabin residents, and rockfalls from steep bluffs in Lava Beds National Monument could potentially deposit debris across the main park road. Ground shaking could also loosen blocks on cave roofs, endangering park visitors exploring the lava-tube caves. There is also a small possibility that buildings could be damaged by ground shaking and roads could be disrupted by faulting.

\section{Event Frequency and Probability Timing of Magmatic Events}

The ages of postglacial lavas were determined by radiocarbon dating of, for example, tree remnants in the edges of lava flows (fig. 14). Stratigraphic relationships and paleomagnetic studies provide additional indirect dating and constraints on the ages of units (fig. 15). By obtaining precise paleomagnetic directions from outcrops in radiocarbon-dated units and determining that other vents and lava flows record the same paleomagnetic direction, it is possible to discover groups of flows and lava domes that share the same eruptive age, even if not dated directly by radiometric means.

On figure 15 we summarize the timing of postglacial eruptive events (see also table 1). The timing of the events clearly indicates that eruptions have occurred in episodes during postglacial time; thus average eruptive intervals likely have little actual significance. During episodes, the frequency of activity is significantly higher than the calculated average. During the 5,200-year time span of the late Holocene, the total time span of the three eruptive episodes is $\sim 500$ years, $<10$ percent of the total time. Moreover, during those 500 years, the 9 eruptions likely each lasted from a few days (Black Crater and Ross Chimneys, fig. 3) to perhaps as long as a few decades (Glass Mountain, fig. 3). Therefore, eruptive activity was probably occurring $<5$ percent of the time during the episodes, and $<1$ percent of the time during the past 5,200 years.

We also portray on figure 15 the apparent timing implied for intrusive events. Petrologic evidence for multiple intrusions of mafic magma involved in generating the erupted silicic lavas, combined with the documented quenched inclusions, suggests a plausible total of at least 20 intrusive and extrusive events, or approximately one every 250 years on average. Very likely, this

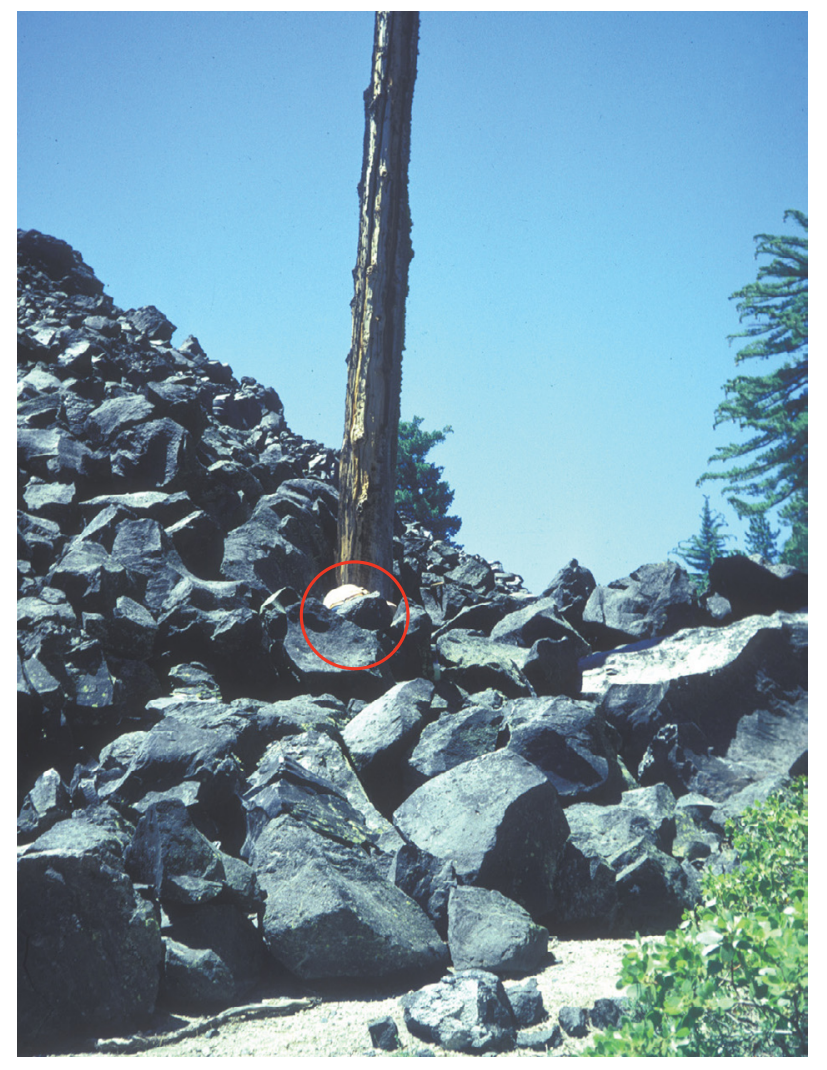

Figure 14. Dead cedar tree in edge of Glass Mountain flow. Tree was killed by the lava flow. Person taking sample from lowermost exposed part of tree is circled. Radiocarbon dating indicates that the eruption occurred about 950 years ago. 
is a minimum estimate of the total number of magmatic events. Any such intrusive event is likely to be accompanied by seismic activity and perhaps by measurable ground movements. Such earthquake activity and measured ground movements would not necessarily indicate that an eruption will soon follow. A possible dike intrusion occurred in 1910, when numerous earthquakes occurred and to the north of Glass Mountain "a fissure about one-half mile long opened up during a very pronounced shake" (Finch, 1928). Flames and blue mud were reported the same year, although Donnelly-Nolan and others (1990) found no deposit or vent indicating an eruption.

\section{Probability of Occurrence and Likely Volumes of Future Eruptions}

The chronology of postglacial eruptive units in table 1 is based on radiocarbon dating combined with constraints from paleomagnetic directions as discussed in a companion report online (Nathenson and others, 2007; http://pubs.usgs.gov/ sir/2007/5174/b/). From the chronology, the time intervals between eruptions can be analyzed for the probability distribution that fits the available data. The usual analysis involves an exponential distribution for a Poisson process, but the disparate eruption time intervals from the episodic character of the postglacial eruptions of MLV indicate that this is not a good model. A better match is a probability distribution called the mixed exponential (Nathenson and others, 2007).
The modeled probability distributions can then be used to calculate the conditional probability of an eruption, given the time since the last eruption (fig. 16). For the mixed exponential distribution, the probability of an eruption decreases as the time since the last eruption increases. It is now 947 years since the last known eruption at Medicine Lake (890 cal. yr BP plus 57 years since 1950 to 2007), and the probability of an eruption in the next year is 0.00028 for the mixed exponential (one chance in 3,600). The probability of an eruption in the next year for an exponential distribution does not depend on the time since the last eruption (fig. 16) and has a constant value of 0.0013 (one chance in 770). Following an eruption, the probability of an eruption in the next year for the mixed exponential distribution (fig. 16) is much greater ( 0.013 or one chance in 77 ). This higher value of probability confirms the intuitive notion that an eruption is more likely while in an episode than between episodes.

If there is an eruption, a graph (fig. 17) constructed from the data in table 1 for volumes and areas of the postglacial eruptions can be used to estimate the probability of various sizes of eruptions. Over most of the range of volumes and areas, the probability is approximately logarithmic. The probability of an eruption producing deposits greater than $1 \mathrm{~km}^{3}$ in volume is about 0.1 (one chance in 10), whereas the probability that the volume is greater than $0.1 \mathrm{~km}^{3}$ is about 0.4 (one chance in 2.5). Thus most eruptions will be relatively small in volume. The probability that the area covered during an erup-

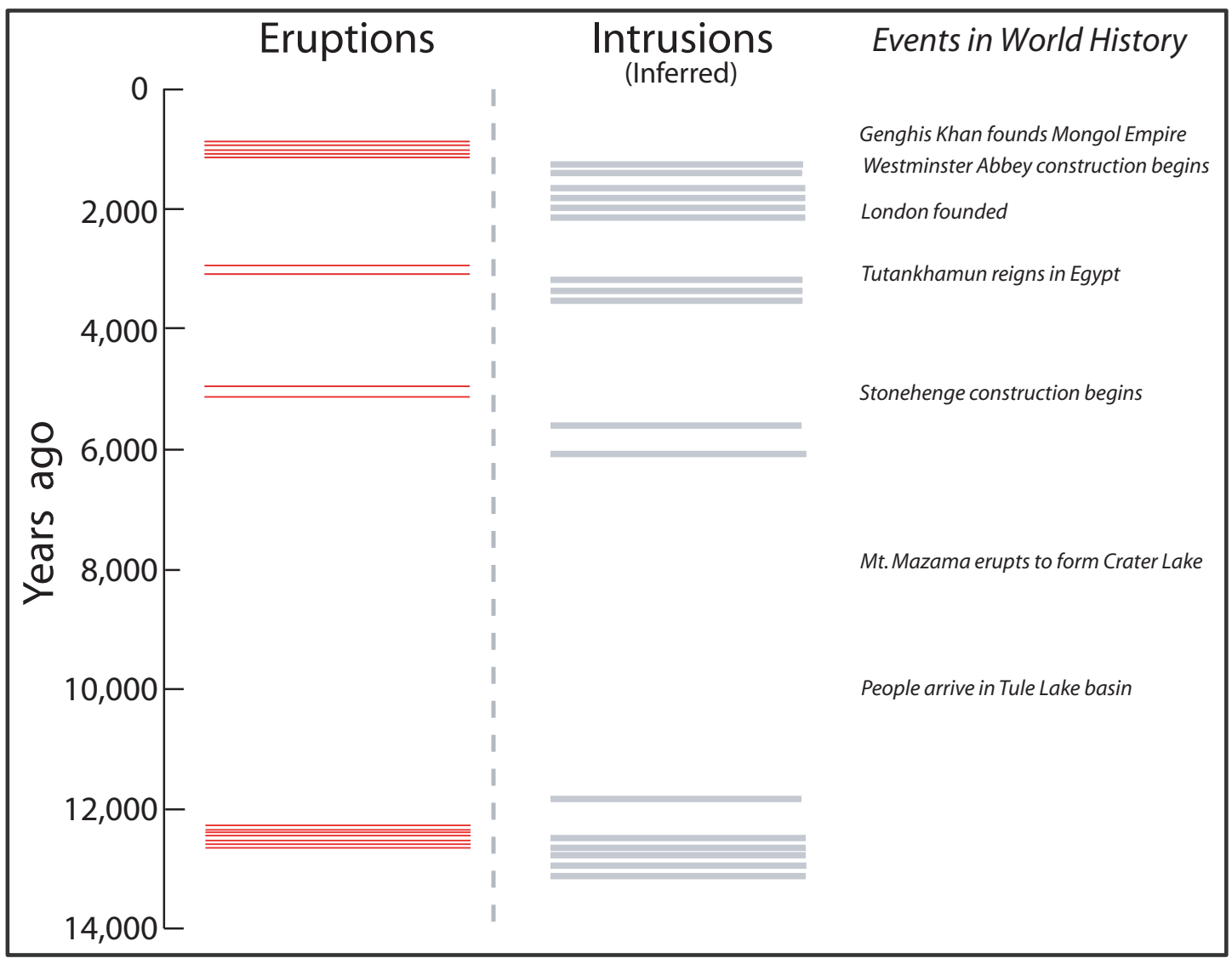

Figure 15. Timing of postglacial eruptions (red lines in first column) and inferred intrusions Igray lines in second column) at Medicine Lake volcano. Intrusive events are inferred from the presence of quenched magmatic inclusions in erupted lavas or from petrologic studies. Events in world and regional history are shown for comparison. 


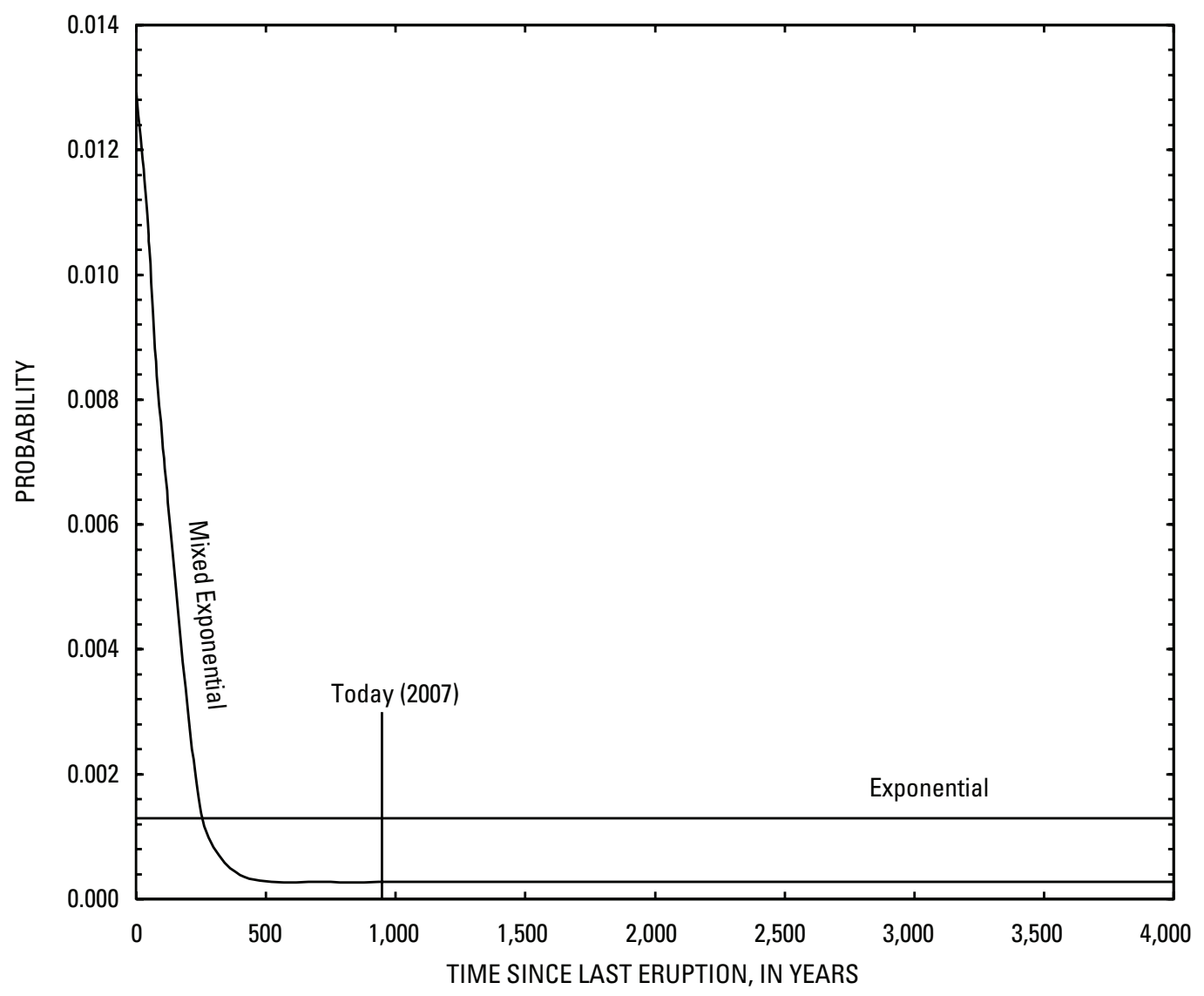

Figure 16. Conditional probability for an eruption at Medicine Lake volcano. The conditional probability shown is the probability that an eruption will occur in the next year, given a time since the last eruption. For the exponential distribution, the conditional probability does not depend on the time since the last eruption, and the estimate of the conditional probability is 0.0013 . For the mixed exponential distribution, which is a good model for eruptions that are clustered in episodes as has occurred at Medicine Lake volcano, the estimate of the current conditional probability is 0.00028 .

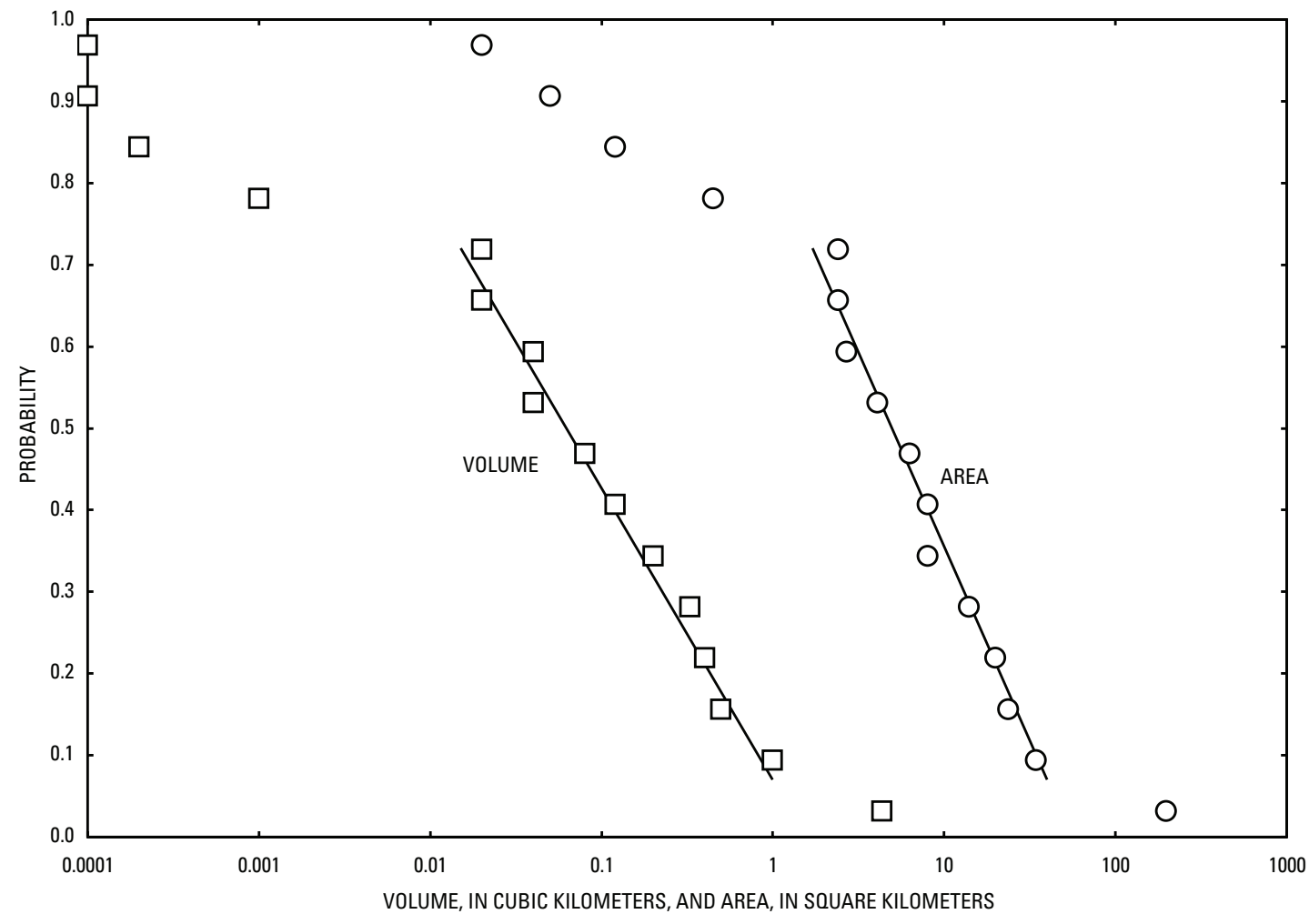

Figure 17. Probability that an eruption at Medicine Lake volcano will have a volume or area greater than a given value. Data from table 1 were used to create cumulative probability distributions. 
tion will be larger than $30 \mathrm{~km}^{2}$ is 0.1 (one chance in 10), and the probability that the area is larger than $8 \mathrm{~km}^{2}$ is about 0.4 (one chance in 2.5). Thus the eruptions are likely to be areally extensive. Two of the 16 postglacial eruptions produced significant amounts of tephra (fig. 9), and so the probability of a future eruption also producing significant tephra is about 0.13 .

\section{Volcano Monitoring and Response}

Volcanic eruptions are typically preceded over periods of days to years by precursory phenomena related to the rise of magma toward the surface. Monitoring of changes in seismic activity, ground deformation, and gaseous emissions provide the opportunity to make forecasts of expected hazards within the known history of eruptive activity at a volcano.

Two seismic stations are installed at Medicine Lake volcano (fig. 13), one on the upper northwest side at Little Mount Hoffman (fig. 18) and the other within the caldera. Data from the seismometers are transmitted to USGS offices in Menlo Park, California. A report on seismic monitoring at Cascade volcanic centers (Moran, 2004) states that MLV has the second-worst theoretical seismic detection threshold in the Cascades. That report further states that at least two seismic stations should be added north and east of Medicine Lake. Given the dispersed vents on MLV, it would be important to be able to locate seismic events with some precision to determine where an eruption is likely to occur. The existing seismic network is not adequate to do this, especially for small events that might signal an eruption.

Changes in ground movement have been measured by careful leveling work (Dzurisin and others, 1991; Dzurisin and others, 2002; Poland and others, 2006), but such studies involve weeks of work by many people, are performed on an intermittent basis, and can only be done during summer months when the volcano is free of snow. No USGS Global Positioning System (GPS) equipment exists at MLV to monitor ground movements on a real-time basis.

Published rates of magma ascent in volcanoes (Rutherford and Gardner, 2000; Buck and others, 2006) vary from 0.01 to $2 \mathrm{~m} / \mathrm{sec}$ and are based on a variety of data including seismic monitoring of eruptions in Iceland and at Mount St. Helens. Geophysical and petrologic data at MLV indicate depths of 3 to $7 \mathrm{~km}$ for a probable existing magma reservoir. From $6 \mathrm{~km}$ depth at a rate of $0.01 \mathrm{~m} / \mathrm{sec}$, magma would arrive at the surface in about 7 days. Magma traveling from just $3 \mathrm{~km}$ depth at a rate of $2 \mathrm{~m} / \mathrm{sec}$ would reach the surface in less than half an hour. However, it is important to remember that days to weeks of seismic activity are likely to precede any eruptive activity. Despite the scarcity of monitoring equipment on the volcano, felt earthquakes would almost certainly give warning of an impending eruption. In the event of volcanic unrest such as noticeable felt seismicity, additional instruments would be deployed. Given the probable shallow depth of magma, the

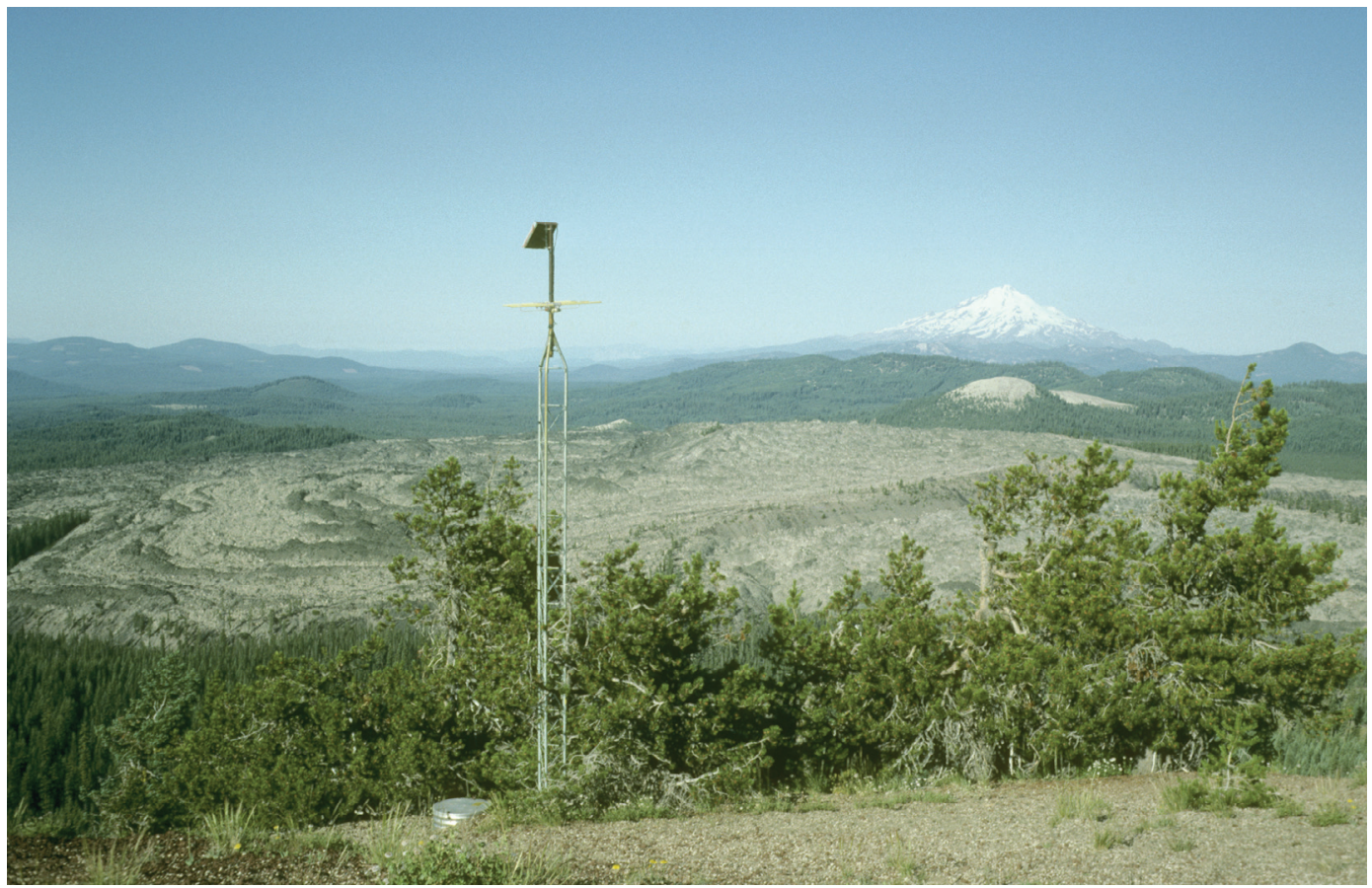

Figure 18. This seismometer installation on the upper west side of Medicine Lake volcano at Little Mount Hoffman is one of only two seismic instruments that are located on the volcano. View is southwest across the Little Glass Mountain flow that erupted about 1,000 years ago. Mount Shasta is on the horizon. 
possible short times of ascent to the surface, and the frequency of eruptive and intrusive events at MLV during the late Holocene, it would be important to have monitoring instruments in place before signs of actual eruptive activity occur (Ewert and others, 2005). It is also possible that ground deformation monitoring by GPS might provide earlier indications of a change in the magma system, such as inflation of the caldera area, as contrasted with the ongoing subsidence.

In order to be well monitored in real time, MLV would potentially need installation of 12 to 20 seismic stations and 12 to 17 continuous GPS stations processed for daily solutions, in addition to airborne gas surveys and application of remote sensing techniques, according to the report of the proposed National Volcano Early Warning System (NVEWS) (Ewert and others, 2005). The information generated by these monitoring techniques would be evaluated by USGS scientists for any changes such as an increase in microseismicity. Monitor- ing would involve personnel at the USGS Cascades Volcano Observatory in Vancouver, Washington, in addition to seismic monitoring at the USGS office in Menlo Park, California. Procedures for eruption notification and dissemination of information are included in this report as table 2, the USGS alert-notification system (Gardner and Guffanti, 2006).

Additional related information can be obtained online at the Web site for the USGS Volcano Hazards Program: http:// volcanoes.usgs.gov/. Information about volcanic ash is available at http://volcanoes.usgs.gov/ash/ and at http://www.ivhhn.org/, where two pamphlets (The Health Hazards of Volcanic Ash; a Guide for the Public, and Guidelines on Preparedness Before, During and After an Ashfall) are available. Information about volcano monitoring can be obtained at http://volcanoes.usgs. gov/About/What/Monitor/monitor.html. A fact sheet describing the USGS National Volcano Early Warning System assessment is online at http://pubs.usgs.gov/2006/fs/2006/3142/.

Table 2. The USGS Alert-Notification System for Volcanic Activity (from Gardner and Guffanti, 2006).

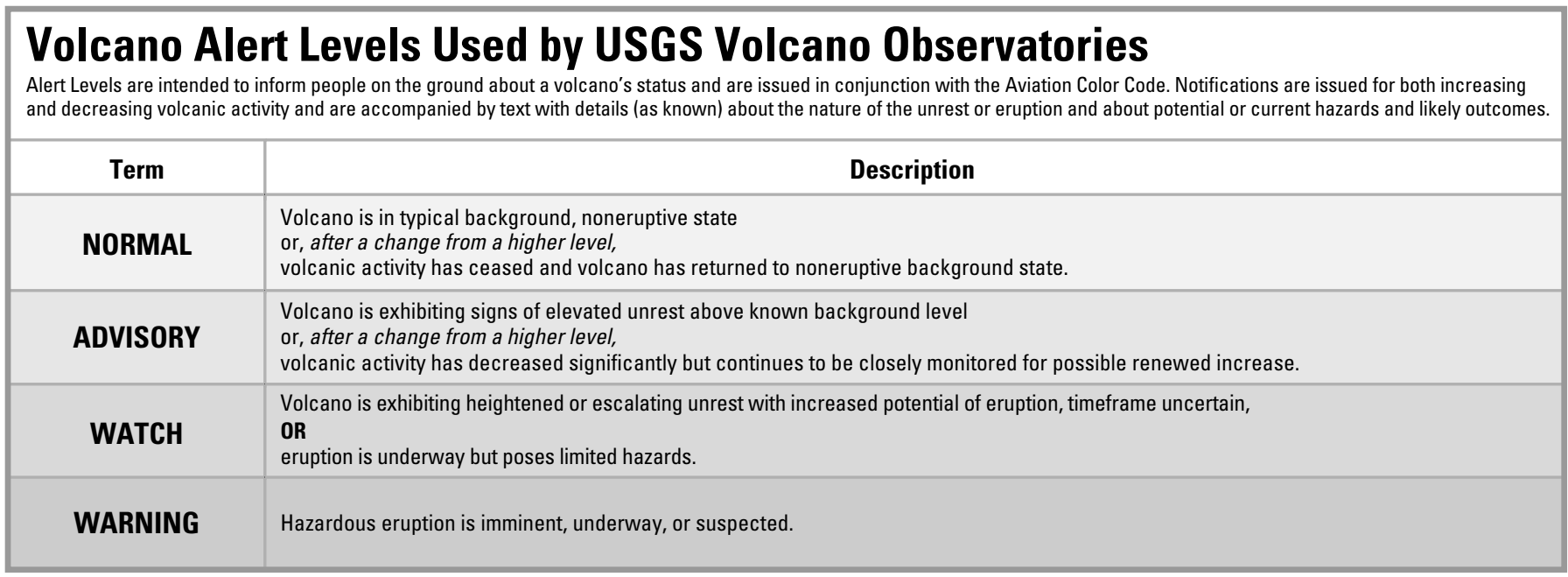

\section{Aviation Color Code Used by USGS Volcano Observatories}

Color codes, which are in accordance with recommended International Civil Aviation Organization (ICA0) procedures, are intended to inform the aviation sector about a volcano's status and are issued in conjunction with an Alert Level. Notifications are issued for both increasing and decreasing volcanic activity and are accompanied by text with details (as known) about the nature of the unrest or eruption, especially in regard to ash-plume information and likely outcomes.

\begin{tabular}{|c|l|}
\hline \multicolumn{1}{|c|}{ Color } & \multicolumn{1}{c|}{ Description } \\
\hline GREEN & $\begin{array}{l}\text { Volcano is in typical background, noneruptive state } \\
\text { or, after a change from a higher level, } \\
\text { volcanic activity has ceased and volcano has returned to noneruptive background state. }\end{array}$ \\
\hline YELLOW & $\begin{array}{l}\text { Volcano is exhibiting signs of elevated unrest above known background level } \\
\text { or, after a change from a higher level, } \\
\text { volcanic activity has decreased significantly but continues to be closely monitored for possible renewed increase. }\end{array}$ \\
\hline ORANGE & $\begin{array}{l}\text { Volcano is exhibiting heightened or escalating unrest with increased potential of eruption, timeframe uncertain, } \\
\text { OR } \\
\text { eruption is underway with no or minor volcanic-ash emissions [ash-plume height specified, if possible]. }\end{array}$ \\
\hline RED & $\begin{array}{l}\text { Eruption is imminent with significant emission of volcanic ash into the atmosphere likely } \\
\text { OR } \\
\text { eruption is underway or suspected with significant emission of volcanic ash into the atmosphere [ash-plume height specified, if possible]. }\end{array}$ \\
\hline
\end{tabular}




\section{References Cited}

Bargar, K.E., 2001, Fluid-inclusion studies of hydrothermal minerals from geothermal drill holes at Medicine Lake volcano, northern California: California Geology, v. 54, no. 5, p. 12-21.

Bennett, J.H., Sherburne, R.W., Cramer, C.H., Chesterman, C.W., and Chapman, R.H., 1979, Stephens Pass earthquakes, Mount Shasta - August 1978: California Geology, v. 32 , no. 2, p. 27-34.

Buck, W.R., Einarsson, P., and Brandsdottir, B., 2006, Tectonic stress and magma chamber size as controls on dike propagation; constraints from the 1975-1984 Krafla rifting episode: Journal of Geophysical Research, v. 111, B12404, doi: 10.1029/2005JB003879, 15 p.

Champion, D.E., and Donnelly-Nolan, J.M., 1994, Duration of eruption at the Giant Crater lava field, Medicine Lake volcano, California, based on paleomagnetic secular variation: Journal of Geophysical Research, v. 99, no. B8, p. 15595-15604.

Champion, D.E., Donnelly-Nolan, J.M., Lowenstern, J.B., and Miller, C.D., 2005, Paleomagnetic data identify post-glacial eruptive episodes and their duration at Medicine Lake volcano, California [abs.]: Geological Society of America Abstracts with Programs, v. 37, no. 4., p. 67.

Chiarabba, C., Amato, A., and Evans, J.R., 1995, Variations on the NeHT high-resolution tomography method; a test of technique and results for Medicine Lake volcano, northern California: Journal of Geophysical Research, v. 100, no. B3, p. 4035-4052.

Childs, J.R., Lowenstern, J.B., Phillips, R.L., Hart, P., Rytuba, J.J., Barron, J.A., Starratt, S.W., and Spaulding, S., 2000, Bathymetric, geophysical and geologic sample data from Medicine Lake, Siskiyou County, northern California: U.S. Geological Survey Open File Report OF 00-043 [http://geopubs.wr.usgs.gov/open-file/of00-043/ (last accessed August 14, 2007)].

Donnelly-Nolan, J.M., 1988, A magmatic model of Medicine Lake volcano, California: Journal of Geophysical Research, v. 93 , p. 4412-4420.

Donnelly-Nolan, J.M., 2006, Chemical analyses and K-Ar ages of samples from 13 drill holes, Medicine Lake volcano, California: U.S. Geological Survey Open-File Report 2006-1041, 20 p.

Donnelly-Nolan, J.M., in press, Geologic map of Medicine Lake volcano, northern California: U.S. Geological Survey Scientific Investigations Map 2927, scale 1:50,000.

Donnelly-Nolan, J.M., and Champion, D.E., 1987, Geologic map of Lava Beds National Monument, northern California: U.S. Geological Survey Map I-1804, scale 1:24,000.
Donnelly-Nolan, J.M., and Lanphere, M.A., 2005, Argon dating at and near Medicine Lake volcano, California; results and data: U.S. Geological Survey Open-File Report 20051416, $37 \mathrm{p}$.

Donnelly-Nolan, J.M., Champion, D.E., Miller, C.D., Grove, T.L., and Trimble, D.A., 1990, Post-11,000-year volcanism at Medicine Lake volcano, Cascade Range, northern California: Journal of Geophysical Research, v. 95, p. 19693-19704.

Donnelly-Nolan, J.M., Champion, D.E., Grove, T.L., Baker, M.B., Taggart, J.E., Jr., and Bruggman, P.E., 1991, The Giant Crater lava field; geology and geochemistry of a compositionally zoned, high-alumina basalt to basaltic andesite eruption at Medicine Lake volcano, California: Journal of Geophysical Research, v. 96, no. B13, p. 2184321863.

Donnelly-Nolan, J.M., Champion, D.E., Ramsey, D.W., and Lanphere, M.A., 2005, The basalt of Yellowjacket Butte, another large and interesting lava flow at Medicine Lake volcano, northern California, USA: Eos (American Geophysical Union Transactions), v. 86, no. 52, Abstract V53B-1562.

Dzurisin, D., Donnelly-Nolan, J.M., Evans, J.R., and Walter, S.R., 1991, Crustal subsidence, seismicity, and structure near Medicine Lake volcano, California: Journal of Geophysical Research, v. 96, p. 16319-16333.

Dzurisin, D., Poland, M.P., and Bürgmann, R., 2002, Steady subsidence of Medicine Lake volcano, northern California, revealed by repeated leveling surveys: Journal of Geophysical Research, v. 107, no. B12, p. 2372, doi: 10.1029/2001JB000893.

Evans, J.R., and Zucca, J.J., 1988, Active high-resolution seismic tomography of compressional wave velocity and attenuation structure at Medicine Lake volcano, northern California Cascade Range: Journal of Geophysical Research, v. 93, no. B12, p. 15016-15036.

Ewert, J.W., Guffanti, M., and Murray, T.L., 2005, An assessment of volcanic threat and monitoring capabilities in the United States; framework for a National Volcano Early Warning System: U.S. Geological Survey Open-File Report 2005-1164, 62 p.

Fierstein, J., and Nathenson, M., 1992, Another look at the calculation of fallout tephra volumes: Bulletin of Volcanology, v. 54, p. 156-167.

Finch, R.H., 1928, Lassen report no. 14: Volcano Letter 161 (reprinted in The Volcano Letters, edited by R.S. Fiske, T. Simkin, and E.A. Nielsen, Smithsonian Institution, Washington, D.C., 1987).

Fink, J.H., and Pollard, D.D., 1983, Structural evidence for dikes beneath silicic domes, Medicine Lake Highland Volcano, California: Geology, v. 11, p. 458-461. 
Gardner, C.A., and Guffanti, M.C., 2006, U.S. Geological Survey's alert notification system for volcanic activity: U.S. Geological Survey Fact Sheet 2006-3139, 4 p.

Gardner, C.A., Scott, K.M., Miller, C.D., Myers, Bobbie, Hildreth, Wes, and Pringle, P.T., 1995, Potential volcanic hazards from future activity of Mount Baker, Washington: U.S. Geological Survey Open-File Report 95-498, 16 p., 1 plate, scale 1:100,000.

Grove, T.L., and Donnelly-Nolan, J.M., 1986, The evolution of young silicic lavas at Medicine Lake volcano, California; implications for the origin of compositional gaps in calc-alkaline series lavas: Contributions to Mineralogy and Petrology, v. 92, p. 281-302.

Grove, T.L., Kinzler, R.J., Baker, M.B., Donnelly-Nolan, J.M., and Lesher, C.E., 1988, Assimilation of granite by basaltic magma at Burnt Lava flow, Medicine Lake volcano, northern California; decoupling of heat and mass transfer: Contributions to Mineralogy and Petrology, v. 99, p. 320-343.

Grove, T.L., Donnelly-Nolan, J.M., and Housh, T., 1997, Magmatic processes that generated the rhyolite of Glass Mountain, Medicine Lake volcano, N. California: Contributions to Mineralogy and Petrology, v. 127, p. 205-223.

Heiken, Grant, 1978, Plinian-type eruptions in the Medicine Lake Highland, California, and the nature of the underlying magma: Journal of Volcanology and Geothermal Research, v. 4, p. 375-402.

Hill, B.E., Connor, C.B., Jarzemba, M.S., LaFemina, P.C., Navarro, M., and Strauch, W., 1998, 1995 eruptions of Cerro Negro volcano, Nicaragua, and risk assessment for future eruptions: Geological Society of America Bulletin, v. 110 , no. 10 , p. $1231-1241$.

Hoblitt, R.P, Miller, C.D., and Scott, W.E., 1987, Volcanic hazards with regard to siting nuclear-power plants in the Pacific Northwest: U.S. Geological Survey Open-File Report 87-297, 196 p.

Hulen, J.B., and Lutz, S.J., 1999, Altered volcanic rocks as hydrologic seals on the geothermal system of Medicine Lake Volcano, California: Geothermal Resources Council Bulletin, v. 28, no. 7, p. 217-222.

Lipman, P.W., and Mullineaux, D.R., eds., 1981, The 1980 eruptions of Mount St. Helens, Washington: U.S. Geological Survey Professional Paper 1250, 844 p.

Lorenz, Volker, 2007, Syn- and posteruptive hazards of maardiatreme volcanoes: Journal of Volcanology and Geothermal Resources, v. 159, p. 285-312.

Mastin, L.G., 1991, The roles of magma and groundwater in the phreatic eruptions at Inyo Craters, Long Valley Caldera, California: Bulletin of Volcanology, v. 53, p. 579-596.
Mastin, L.G., and Witter, J.B., 2000, The hazards of eruptions through lakes and seawater: Journal of Volcanology and Geothermal Research, v. 97, p. 195-214.

Miller, C.D., 1989, Potential hazards from future volcanic eruptions in California: U.S. Geological Survey Bulletin 1847, 17 p., 2 plates.

Moran, S.C., 2004, Seismic monitoring at Cascade volcanic centers, 2004 — status and recommendations: U.S. Geological Survey Scientific Investigations Report 2004-5211, 22 p.

Nairn, I.A., 1979, Rotomahana-Waimangu eruption, 1886; base surge and basalt magma: New Zealand Journal of Geology and Geophysics, v. 22, p. 363-378.

Nathenson, Manuel, Donnelly-Nolan, J.M., Champion, D.E., and Lowenstern, J.B., 2007, Chronology of postglacial eruptive activity and calculation of eruption probabilities for Medicine Lake volcano, Northern California: U.S. Geological Survey Scientific Investigation Report 2007-5174-B, 10 p. [http://pubs.usgs.gov/sir/2007/5174/b/].

Pitt, A.M., Hill, D.P., Walter, S.W., and Johnson, M.J.S., 2002, Midcrustal, long-period earthquakes beneath northern California volcanic areas: Seismological Research Letters, v. 73, no. 2, p. 144-152.

Poland, M., Burgmann, R., Dzurisin, D., Lisowski, M., Masterlark, T., Owen, S., and Fink, J., 2006, Constraints on the mechanism of long-term, steady subsidence at Medicine Lake volcano, northern California, from GPS, leveling, and InSAR: Journal of Volcanology and Geothermal Research, V. 150, p. $55-78$.

Rutherford, M.J., and Gardner, J.E., 2000, Rates of magma ascent, in Sigurdsson, H., ed., Encyclopedia of Volcanoes: Academic Press, p. 207-217.

Walter, S., and Dzurisin, D., 1989, The September 1988 earthquake swarm at Medicine Lake volcano, northern California [abs.]: Eos (American Geophysical Union Transactions), v. 70, no. 43, p. 1189-1190.

Waters, A.C., and Fisher, R.V., 1971, Base surges and their deposits; Capelinhos and Taal volcanoes: Journal of Geophysical Research, v. 76, p. 5596-5613.

Wills, C.J., 1991, Active faults north of Lassen Volcanic National Park, northern California: California Geology, v. 44, no. 3, p. 51-58.

Wolfe, E.W., and Hoblitt, R.P., 1996, Overview of the eruptions, in Newhall, C.G., and Punongbayan, R.S., eds., Fire and mud-eruptions and lahars of Mount Pinatubo, Philippines: Philippine Institute of Volcanology and Seismology and University of Washington Press, p. 3-20.

Zlotnicki, J., Boudon, G., and Le Mouel, J.-L., 1992, The volcanic activity of La Soufriere of Guadeloupe (Lesser Antilles); structural and tectonic implications: Journal of Volcanology and Geothermal Research, v. 49, p. 91-104. 


\section{Glossary}

Note: Terms shown in bold type within definitions are separately defined in this listing.

Agglutinate. A welded pyroclastic deposit; term is commonly used for deposits of bombs fused while hot and viscous. Agglutinate typically occurs in spatter cones.

Andesite. Volcanic rock, typically dark gray to black, with about 57-63 percent silica.

Ash. Fine fragments (less than $2 \mathrm{~mm}$ across) of volcanic rock formed in an explosive eruption.

Ash-flow tuff. The deposit of a hot, chaotic mixture of pumice, ash, and gas (pyroclastic flow) that travels rapidly (as fast as tens of meters per second) away from a volcanic vent during an explosive eruption.

Basalt. Volcanic rock with about 47-53 percent silica, typically gray to black. Basaltic lavas are more fluid than andesites or dacites, which contain more silica.

Basaltic andesite. Volcanic rock, commonly dark gray to black, with about 53-57 percent silica.

Base surge. A ring-shaped cloud of gas and suspended solid debris that moves radially outward at high velocity from the base of a vertical eruption column. Can accompany phreatomagmatic eruptions.

Bomb (volcanic). Fragments ejected explosively from a volcanic vent on an arcuate, ballistic trajectory, much like a cannonball. Typically are found as part of cinder cones formed over mafic vents.

Caldera. A large, basin-shaped volcanic depression, more or less circular in form; typically more than $2 \mathrm{~km}$ across. Commonly formed by collapse during withdrawal or ejection of a large volume of magma that leaves the roof of the magma reservoir unsupported. At Medicine Lake volcano, the caldera has been created both by withdrawal of magma and by construction of a rim resulting from eruption of vents around the basin.

Cinder cone. A conical hill formed by accumulation of solidified bubblerich droplets, clots (scoria), and bombs of lava that fall around the vent of a single basaltic or andesitic eruption.

Dacite. Volcanic rock with about 64-69 percent silica. Dacite lavas are viscous and tend to form thick blocky lava flows or steep-sided piles of lava called lava domes. Dacitic magmas tend to erupt explosively, thus also ejecting abundant ash and pumice.

Dike. A tabular igneous intrusion, typically much longer than it is wide.

Dome. A steep-sided mass of viscous and often blocky lava extruded from a vent; typically has a rounded top and covers a roughly circular area. May be isolated (like the Medicine Lake Glass Flow) or, alternatively, associated with lobes or flows of lava from the same vent. Typically silicic (rhyolite or dacite) in composition.

Effusive eruption. An eruption that produces mainly lava flows and domes (as opposed to an explosive eruption).

Ejecta. Material explosively ejected from a volcano.

Eruption column. The ascending, vertical part of the mass of erupting debris and volcanic gas that rises directly above a volcanic vent. Higher in the atmosphere, columns usually spread laterally into plumes or umbrella clouds.

Explosive eruption. An energetic eruption that produces mainly ash, pumice, and fragmental ballistic debris (as opposed to an effusive eruption).

Fallout. A general term for all the ash and debris that falls to earth (also known as ashfall) from an eruption cloud.

Fumarole. A vent from which steam and volcanic gases issue.
Holocene. The youngest geologic time period, considered to include the past approximately 11,500 years. It is almost equivalent to postglacial time.

Hydrothermal explosion. Explosion that can occur when hot water within a volcano's hydrothermal (hot water) system flashes to steam, breaking rocks and throwing them into the air.

Igneous. Refers to rocks formed by solidification from magma.

Lahar. Also called a volcanic mudflow or debris flow. A mixture of water and volcanic debris that moves rapidly downstream. Consistency can range from that of muddy dishwater to that of wet cement, depending on the ratio of water to debris.

Lava. Molten rock (magma) that reaches the earth's surface and maintains its integrity as a fluid or viscous mass, rather than exploding into fragments.

Mafic. Describes magma that contains lower amounts of silica and is generally less viscous and less gas-rich than silicic magma. Tends to erupt effusively, as lava flows. Includes andesites (57-63 percent $\left.\mathrm{SiO}_{2}\right)$, basaltic andesites $(53-57$ percent $\mathrm{SiO}_{2}$ ), and basalts (47-53 percent $\mathrm{SiO}_{2}$ ).

Magma. Molten rock beneath the Earth's surface.

Paleomagnetic studies. Investigations of the orientation and(or) intensity of the Earth's magnetic field in the past, as recorded in geologic materials. The magnetic poles wander about the Earth's axis of rotation, and the paleomagnetic pole position at the time of cooling of a volcanic rock is "frozen in" by magnetic minerals. An empirical calibration of this "secular variation" over time allows eruption ages to be constrained and isolated outcrops to be correlated with one another. 
Petrologic. Petrology is the study of rocks, including their occurrence, composition, and origin.

Phreatic eruption. An eruption that primarily involves steam explosions, usually ground water flashed into steam by the heat of subsurface magma.

Phreatomagmatic eruption. An eruption that involves both magma and water, which typically interact explosively, leading to concurrent ejection of steam and pyroclastic fragments.

Pleistocene. The geologic time period preceding the Holocene. Extends from 1.8 million years ago to about 11,500 years ago.

Postglacial. Refers to the time since the end of the last major ice age (about 13,000 years ago at Medicine Lake volcano).

Pumice. Highly vesicular volcanic ejecta, typically silicic in composition. It is essentially magma that has been frothed up by escaping gases and then cooled and solidified during eruption. Rhyolitic pumice is typically of low enough density that it floats on water. Near a vent, hot pumice can accumulate and form a pumice cone.

Pyroclastic. General term applied to volcanic products or processes that involve explosive ejection and fragmentation of erupting material. Literally means "fire-broken."

Pyroclastic flow. A hot (typically $>800^{\circ} \mathrm{C}$ ), chaotic mixture of rock fragments, gas, and ash that travels rapidly (tens of meters per second) away from a volcanic vent or collapsing flow front.

Rhyolite. Volcanic rock with 70-77 percent silica. Rhyolitic lavas are viscous and tend to form thick blocky lava flows or steepsided piles of lava called lava domes. Rhyolite magmas tend to erupt explosively, commonly also producing abundant ash and pumice.

Scoria. Vesicular volcanic ejecta, essentially magma that has been frothed up by escaping gases. It is a textural variant of pumice, with scoria typically being less vesicular, denser, and usually andesitic or basaltic.

Silica. Silica is silicon dioxide $\left(\mathrm{SiO}_{2}\right)$ the predominant molecular constituent of volcanic rocks and magmas. It tends to polymerize into molecular chains, increasing the viscosity of the magma.
Basaltic magma, having lower $\mathrm{SiO}_{2}$, is fairly fluid, but with increasing contents of $\mathrm{SiO}_{2}$, andesite, dacite, and rhyolite magmas become progressively more viscous. Because it is more difficult for dissolved gas to escape from more viscous magma, higher silica magmas generally erupt more explosively.

Silicic. Describes magma that contains more than $\sim 63$ percent silica and is generally viscous, gas-rich, and tends to erupt explosively. Includes rhyolite and dacite.

Spatter cone. A steep-sided cone constructed of agglutinate at a mafic vent. Most spatter cones are small (typically $10 \mathrm{~m}$ or less in height) and commonly form in linear groups along a fissure.

Tectonic. Relating to structural deformation of the Earth's crust.

Tephra. Any type and size of rock fragment that is forcibly ejected from the volcano and travels an airborne path during an eruption (including ash, bombs, and scoria).

Vent. Any opening at the Earth's surface through which magma erupts or volcanic gases are emitted. 
(7) Printed on recycled paper 